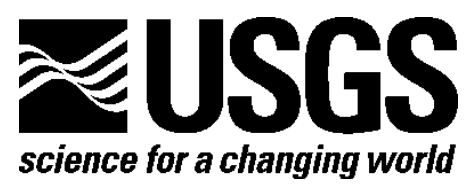

\title{
Earthquake Locations Determined by the Southern Alaska Seismograph Network for October 1971 through May 1989
}

By Kent A. Fogleman, John C. Lahr, Christopher D. Stephens and Robert A. Page

Open-File Report 93-309, v. 1.1 


\section{U.S. Department of the Interior \\ KEN SALAZAR, Secretary}

\section{U.S. Geological Survey \\ Marcia K. McNutt, Director}

U.S. Geological Survey, Reston, Virginia: 1993

Revised 2012

For more information on the USGS-the Federal source for science about the Earth,

its natural and living resources, natural hazards, and the environment-visit

http://www.usgs.gov or call 1-888-ASK-USGS

For an overview of USGS information products, including maps, imagery, and publications, visit $h$ ttp://www.usgs.gov/pubprod

To order this and other USGS information products, visit $h$ ttp://store.usgs.gov

Suggested citation:

Fogleman, K.A., Lahr, J.C., Stephens, C.D., and Page, R.A., 1993, revised 2012, Earthquake locations determined by the southern Alaska seismograph network for October 1971 through May 1989: U.S.

Geological Survey Open-File Report 93-309, Version 1.1, 54 p. and data files, available at http://pubs.usgs.gov/of/1993/0309/.

Any use of trade, product, or firm names is for descriptive purposes only and does not imply endorsement by the U.S. Government.

Although this report is in the public domain, permission must be secured from the individual copyright owners to reproduce any copyrighted material contained within this report. 


\section{Contents}

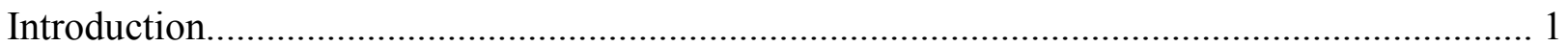

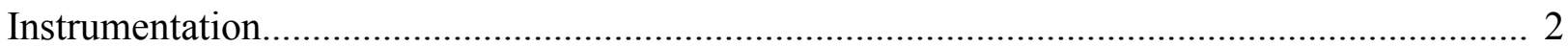

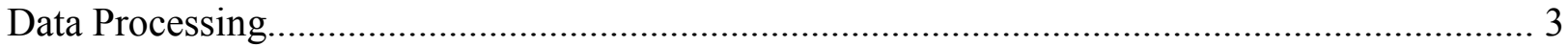

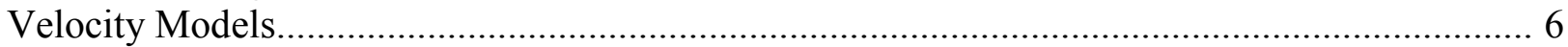

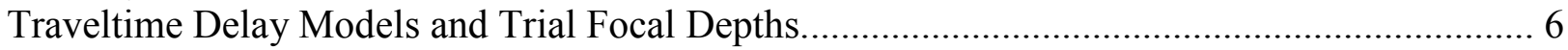

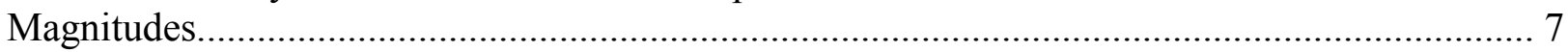

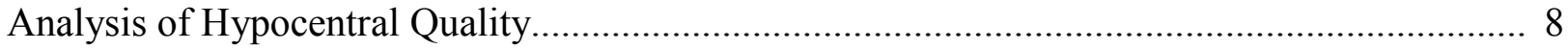

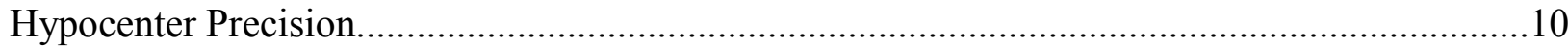

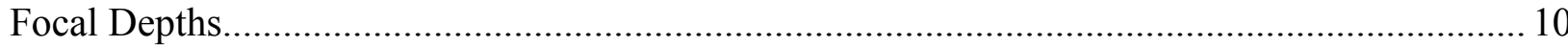

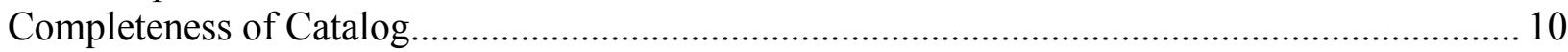

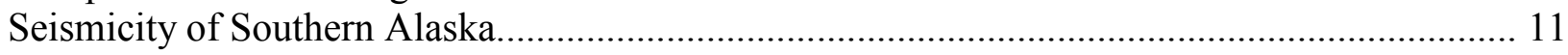

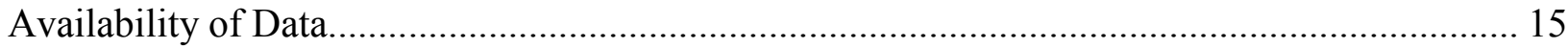

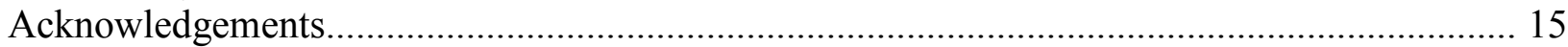

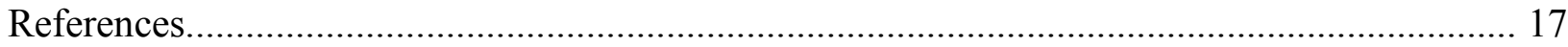

\section{Figures}

1 Map showing principal seismograph stations used in locating earthquakes....................... 21

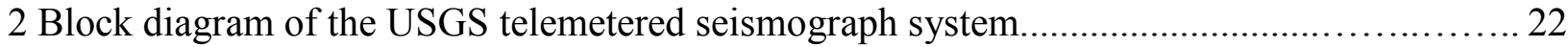

3 System response curves of typical USGS telemetered seismograph stations........................... 23

4 Histogram showing the number of earthquakes located per month......................................... 24

5 Map showing earthquake epicenters with magnitudes greater than 4.0 ................................... 25

6 Map showing earthquake epicenters with depths equal to and deeper than $30 \mathrm{~km}$................. 26

7 Map showing earthquakes epicenters with depths shallower than $30 \mathrm{~km}$................................. 27

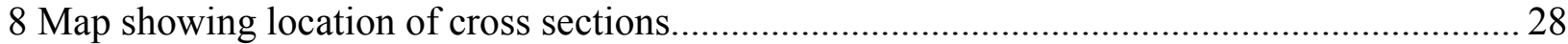

9 Cross sections showing depth distribution of earthquake hypocenters.............................. 29

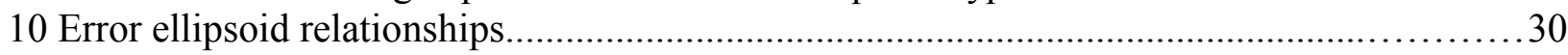

\section{Tables}

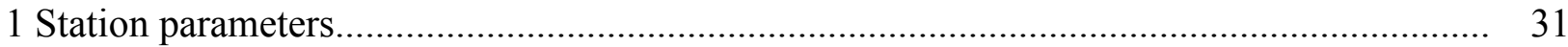

2 Alaska velocity models.............................................................................................. 38

3 Geographical boundaries, starting depths, velocity models, and delay models................. 39

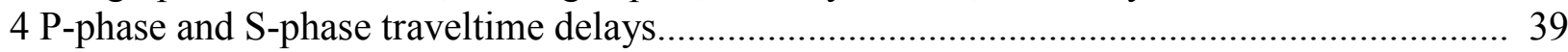

5 Statistics of summary $/$ phase data......................................................... 40

\section{Appendixes}

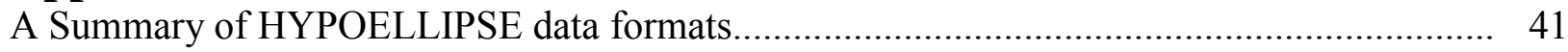

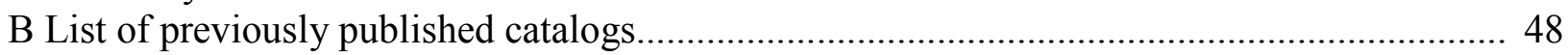

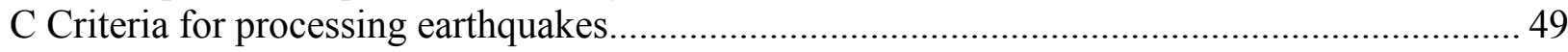




\title{
Earthquake Locations Determined by the Southern Alaska Seismograph Network for October 1971 through May 1989
}

\author{
By Kent A. Fogleman ${ }^{1}$, John C. Lahr², Christopher D. Stephens ${ }^{1,}$ and Robert A. Page ${ }^{3}$ \\ ${ }^{1}$ U.S. Geological Survey, Earthquake Science Center (ESC), Menlo Park, Calif. \\ ${ }^{2}$ U.S. Geological Survey, Geophysicist deceased \\ ${ }^{3}$ U.S. Geological Survey, Geophysicist emeritus, ESC, Menlo Park, Calif.
}

\section{Introduction}

The U.S. Geological Survey (USGS) operated a regional network of seismographs in southern Alaska from 1971 to the mid 1990's. The principal purpose of this network was to record seismic data to be used to precisely locate earthquakes in the seismic zones of southern Alaska, delineate seismically active faults, assess seismic risks, document potential premonitory earthquake phenomena, investigate current tectonic deformation, and study the structure and physical properties of the crust and upper mantle. A task fundamental to all of these goals was the routine cataloging of parameters for earthquakes located within and adjacent to the seismograph network.

The initial network of 10 stations, 7 around Cook Inlet and 3 near Valdez, was installed in 1971. In subsequent summers additions or modifications to the network were made. By the fall of 1973, 26 stations extended from western Cook Inlet to eastern Prince William Sound, and 4 stations were located to the east between Cordova and Yakutat. A year later 20 additional stations were installed. Thirteen of these were placed along the eastern Gulf of Alaska with support from the National Oceanic and Atmospheric Administration (NOAA) under the Outer Continental Shelf Environmental Assessment Program to investigate the seismicity of the outer continental shelf, a region of interest for oil exploration. Since then the region covered by the network remained relatively fixed while efforts were made to make the stations more reliable through improved electronic instrumentation and strengthened antenna systems. The majority of the stations installed since 1980 were operated only temporarily (from one to several years) for special studies in various areas within the network. Due to reduced funding, the network was trimmed substantially in the summer of 1985 with the closure of 15 stations, 13 of which were located in and around the Yakataga seismic gap. To further reduce costs, two telephone circuits were dropped and multiple radio relays were installed in their place. This economy reduced the reliability of these telemetry links. In addition, data collection from the areas around Cordova and Yakutat was compromised by 
the necessity of relying on triggered event recording using PC-based systems (Rogers, 1993) that were not fully developed and which proved to be less reliable than anticipated.

The principal means of recording throughout the time period of this catalog was 20-channel oscillographs on 16-mm film (Teledyne Geotech Develocorder, Model RF400 and 4000D). Initially one Develocorder was operated at the USGS Alaskan headquarters in Anchorage, but in 1972 recording was shifted to the National Oceanic and Atmospheric Administration (NOAA) Palmer Observatory (currently the West Coast and Alaska Tsunami Warning Center). The Develocorders were turned off at the end of May 1989, and after that time recording was done in digital format at the Geophysical Institute of the University of Alaska in Fairbanks (GIUA). Thus, this catalog covers the entire period of film recording.

\section{Instrumentation}

The locations of seismograph stations of the USGS network that contributed to this catalog are shown in Figure 1 along with stations operated by other institutions from which readings were obtained. Station coordinates and operational dates are listed in Table 1. Most of the USGS stations had only single, vertical-component sensors, but horizontal components seismometers were also operated at a few selected sites (marked by asterisks in Table 1).

The instrumentation used in the USGS seismograph network is illustrated in the block diagram in Figure 2. The standard equipment at each field site included: a vertical seismometer with a natural frequency of $1.0 \mathrm{~Hz}$ (Mark Products, Model L-4C); an electronics package consisting of an amplifier, voltage-controlled oscillator (Develco Model 6203 or equivalent) until about 1980, and then an A1VCO with calibrator and gain-ranging (Rogers and others, 1980); and either "aircell" storage batteries, or a solar panel with $80 \mathrm{amp}$-hr storage batteries.

Data were telemetered via a combination of VHF (162-174 MHz) radio links and leased telephone circuits, some of which used satellite links having a $0.27 \mathrm{~s}$ transmission delay per hop. The radio equipment consisted of low-power $(100 \mathrm{~mW})$ transmitters and receivers, many adapted from HT-200 Motorola handie-talkie transceivers, and either Yagi antennae with $9 \mathrm{db}$ directional gain (Scala, Model CAS-150) or log-periodic antennae (Scala, Model CL-150). At the receive sites, where the seismic signals entered the telephone circuits, base-station radio receivers (G.E. Model R46AP66B) with greater sensitivity were used. The central recording facility incorporated a bank of discriminators (USGS designed NCER J101 or Develco Model 6203), four $16 \mathrm{~mm}$-film 20channel oscillographs (Teledyne Geotech Develocorder, Model RF400 and 4000D), a 14-track FM magnetic tape recorder (Bell and Howell Model VR3700B), three 3-channel drum recorders (Teledyne Geotech Helicorder, Model RV301B), and a time-code generator (Datum, Model 9100).

The principle of operation was as follows: the seismometer translated ground velocity into an electrical voltage that was fed into the amplifier/VCO unit. There the amplified voltage caused the frequency of VCO to fluctuate about its center frequency. The frequency-modulated (FM) tone from the amplifier/VCO unit was carried directly to the recording site by VHF radio links and/or voice-grade telephone circuits. Signals from eight seismograph stations could be transmitted on a single telemetry circuit using standard frequency division multiplexing techniques with a $340 \mathrm{~Hz}$ 
separation between carriers and a constant bandwidth of $250 \mathrm{~Hz}$ per channel. The channel center frequencies ranged from 680 to $3,060 \mathrm{~Hz}$. A ninth channel with center frequency of $340 \mathrm{~Hz}$ and $125 \mathrm{~Hz}$ bandwidth was also commonly used. At the recording site the FM seismic signal was demodulated by a discriminator. The demodulated signal, which was simply an amplified and filtered form of the initial signal from the seismometer, was recorded on the oscillograph and tape recorder together with time signals from the time-code generator. Twenty-four hours of data from 18 stations could be recorded on a single $43 \mathrm{~m}$-long roll of 16-mm film, while data from nine stations could be recorded on a single track of a 2,195 m-long, 14-track tape. A number of stations were also recorded on Helicorder records for monitoring purposes.

Figure 3 illustrates the response characteristics of the entire seismic system from seismometer to film viewer. The response level at each station was adjusted in steps of 6 decibels so that the ambient seismic noise produced a small deflection of the trace on the film. As a result, the actual response for an individual station may differ from that of the typical station by a factor of $2,4,8$, etc. The magnification of the typical station was about $6 \times 10^{4}$ at $1 \mathrm{~Hz}$ and $1 \times 10^{6}$ at $10 \mathrm{~Hz}$.

Digital seismic-event recorders were developed internally and deployed to temporarily augment network recording in areas of interest. A description of these instruments can be found in Rogers and Lahr (1986) and Fogleman and Rogers (1987).

\section{Data Processing}

The 16-mm films, magnetic tapes, and Helicorder records were mailed weekly from the Alaska Tsunami Warning Center in Palmer, Alaska to the USGS in Menlo Park, California where the seismic data were processed by the following multi-step routine:

1. Scanning. The scan film, which recorded data from 18 stations distributed throughout the network, was scanned to identify all seismic events, including those of local, regional, and teleseismic origin, and to note the earliest $\mathrm{P}$-arrival time, the time interval between the $\mathrm{P}$ and $\mathrm{S}$ phases (S-P time), and the duration of the signal (F-P coda time) for the first 3 stations. Stations not recorded on the scan film were arranged on the remaining films by geographic region.

2. Timing. For the "well-recorded" local earthquakes identified in the scanning process, the following data were read from each station: P- and S-wave arrival times, direction of first motion, duration of signal in excess of a given threshold amplitude, and period and peak-to-trough amplitude of maximum recorded signal. The $\mathrm{P}$ and $\mathrm{S}$ times were assigned weights according to the reader's confidence of the precision of the picks. The precision was influenced by the impulsiveness of the phases and the recording quality. Weights range from a full weight (coded 0 ) for the highest quality readings to no weight (coded 4) for times too poor to be used for hypocenter determination.

From October 1971 through the end of September 1973, the criteria for choosing earthquakes to be timed were based on S-P times and the number of stations that clearly record the earthquake. Beginning with October 1973, an additional criterion based on the signal duration was 
used. The area within which earthquake locations were routinely determined changed a number of times since 1971. The various criteria from October 1971 to May 1989 used to determine which earthquakes to time are summarized in Appendix C. From September 1, 1985 to May 31, 1989, for example, the area was bounded approximately by longitudes $156^{\circ}$ and $138^{\circ} \mathrm{W}$ and by latitudes $58^{\circ}$ and $62.5^{\circ} \mathrm{N}$, and was subdivided into western and eastern regions at longitude $145^{\circ} \mathrm{W}$. In the western region, only events with average signal durations longer than 30 s were routinely timed. In the eastern region, all earthquakes that were recorded by at least three stations and that produce at least four clear arrivals were timed. These criteria were established to select from the large number of earthquakes recorded by the network those shocks that were of greatest interest to current research objectives. In areas where special studies were being conducted, exceptions to the standard criteria were often made in order to locate more events.

Until October 1982 all of the available data recorded on the Develocorder films were read for each timeable earthquake. Since then, in order to keep the data processing current, only the scan film and the film(s) which contain the stations in the region in which the earthquake occurred were timed. A record of which films were timed for each earthquake was kept with the daily scan sheet.

Due to changes in the distribution of stations, to variations in seismicity rates, and to modifications in the criteria used for selecting which events to locate, the number of shocks located each month varied with time (Figure 4). The large increase seen beginning with March 1979 was due mainly to the aftershock sequence of the February 1979, $\mathrm{M}_{\mathrm{S}}$ 7.1 St. Elias earthquake which elevated the level of activity until the mid 1980's. The gradual decay in the number of events per month from 1979 to 1988 was due partially to decay in the rate of St. Elias aftershocks and to the closure of 15 stations, 13 of which were located in and around the Yakataga seismic gap, in the summer of 1985. Large spikes in the monthly number between 1982 and 1988 were due mainly to aftershock sequences. The large increase beginning in 1989 was due predominantly to the integration of data processed by the Geophysical Institute of the University of Alaska in Fairbanks with the USGS southern Alaska data.

The bulk of the timing was done by projecting the seismic traces from the film onto a onefilm wire-grid or four-film sonic (Astrue and others, 1983) computer-based digitizing table, where the P- and S-phases, maximum amplitude, and coda duration were input as x-y coordinates into a computer and reformatted for input into a hypocentral location program. Since the fall of 1983, some of the timing utilized digital waveform data obtained by digitizing the daily FM magnetic tapes at 100 samples per second. In the latter case an interactive, computer-based processing system (Stevenson, 1978) was used to display the waveforms and to pick the phase data. Starting in July 1988, the Geophysical Institute of the University of Alaska (GIUA), Fairbanks began recording 13 USGS stations along with those in its own network as digital waveform files. All events that triggered the GIUA automatic detection and recording system were located regardless of magnitude or location. Consequently, shocks within the USGS routine processing borders that would normally not have been processed by the USGS were also located. The digital data were timed using the program XPICK (Robinson, 1990). Duplicate readings by GIUA staff for earthquakes processed by the USGS were typically weighted out. 
3. Initial computer processing. The phase data for the timed events were batch processed by computer using the program HYPOELLIPSE (Lahr, 1989, 1999) to obtain origin times, hypocenters, magnitudes and, if desired, first-motion plots for fault-plane solutions. The HYPOELLIPSE computer program determines hypocenters by minimizing differences between observed and computed traveltimes through an iterative least-squares scheme. In many respects the program is similar to HYPO71 (Lee and Lahr, 1972), from which it was derived. Important features available in HYPOELLIPSE, but not in HYPO71, include multiple velocity and delay models, calculation of confidence ellipsoids, and incorporation of a station-history data base to keep the station gains and polarities updated.

The earthquake locations are based on P- and S-arrivals. S-arrivals provide important constraints on epicenters of shocks outside the network, and depths of events in the Wadati-Benioff zones beneath Cook Inlet and the Wrangell volcanoes (see section on Focal Depths). For some large events timed from the films, S-arrivals could not be read at any station because the traces on the film overlapped each other or were too faint to read. However, S-arrivals not readable from the films were often picked on paper records generated from playbacks of the magnetic tapes.

4. Analysis of initial computer results. Each hypocentral solution was checked for: large traveltime residuals (see section on Analysis of Hypocentral Quality), a root-mean-square (RMS) residual greater than $1 \mathrm{~s}$, a focal depth greater than $35 \mathrm{~km}$ in an area where no Wadati-Benioff zone was known to exist, individual station magnitudes which differed from the average event magnitude by more than 0.5 , and a poor spatial distribution of stations. Events with potential timing errors were re-read and additional readings, including those from sources other than the USGS network, were sought for shocks with a poor distribution of recording stations.

Initially, when the network spanned a relatively small area , traveltime residuals greater than $0.4 \mathrm{~s}$ were checked for data that was cataloged. As the network expanded eastward, it became necessary to increase the threshold for checking traveltime residuals due to the increase in the average epicentral distance to the stations used to locate the earthquakes. Beginning with 1978 data, the criterion for checking traveltime residuals was to check: the five closest stations for Presiduals greater than $0.6 \mathrm{~s}$ and S-residuals greater than $1.0 \mathrm{~s}$; the stations beyond the first five and up to $150 \mathrm{~km}$ from the epicenter for P- and S-residuals greater than $0.9 \mathrm{~s}$ and $1.5 \mathrm{~s}$, respectively; and stations with an epicentral distance between 150 to $350 \mathrm{~km}$ for P-residuals greater than $1.5 \mathrm{~s}$ and Sresiduals greater than $2.0 \mathrm{~s}$. Arrivals at stations with epicentral distances greater than $350 \mathrm{~km}$ were generally weighted out by HYPOELLIPSE and checked for P- and S-residuals greater than $2.0 \mathrm{~s}$ and $3.0 \mathrm{~s}$, respectively.

5. Final computer processing. Poor hypocentral solutions were rerun with corrected and/or additional data, and the new solutions were checked for large residuals that might indicate remaining errors. Corrections were made as required before the final computer run. Generally no more than three computer runs were allowed for any earthquake by an analyst. Additional runs were made by a geophysicist to correct problem events. An empirical study of 100 earthquakes from October and November 1979 revealed that correcting all large traveltime residuals for each solution regardless of the overall quality of the solution resulted in little improvement in hypocenter precision and was time consuming. The high-quality solutions with only a few large traveltime 
residuals generally changed less than one minute in latitude and longitude and one $\mathrm{km}$ in depth with additional re-reads and computer runs. Consequently, since January 1980, earthquakes with only a few large traveltime residuals were checked only if the analyst felt the hypocentral solution might be affected.

\section{Velocity Models}

Our experience with locating earthquakes in southern Alaska suggest that significant lateral variations are present in the velocity structure across the network. Such variations might be expected from the complex geology and tectonics of the region (e.g., Plafker, 1967; Page and others, 1986). Over the years different methods have been used to account for variations in the crustal structure across southern Alaska. There have also been changes in the location program HYPOELLIPSE which would modify the computed locations (Lahr, 1989, 1999). For these reasons, all of the earthquake data from October 1971 through May 1989 were relocated using a single set of control parameters. Three velocity models were used in locating the earthquakes (Table 2). The Southern Alaska Model was based on a study of earthquakes below the Kenai Peninsula (Model A, Matumoto and Page, 1969); the Northern Alaska Model was developed by the Geophysical Institute of the University of Alaska, Fairbanks (N. Biswas, personal communication, 1988); the Gulf of Alaska Model was based on a study of the 1987 and 1988, $\mathrm{M}_{\mathrm{w}} 7.9$ and $\mathrm{M}_{\mathrm{w}}$ 7.8, Gulf of Alaska earthquakes (Lahr and others, 1988a) and their aftershocks.

It is recognized that a model comprised of uniform horizontal layers is a poor representation of the actual velocity structure in the vicinity of a subduction zone (Mitronovas and Isacks, 1971; Jacob, 1972, McLaren and Frohlich, 1985); however, such a model does have the advantage of simplifying the computation of traveltimes. In order to determine any bias that might result from the approximation, a set of events in the Wadati-Benioff zone below Cook Inlet was relocated using a ray-tracing program of E. R. Engdahl and incorporating a more realistic, three-dimensional velocity model (Lahr and others, 1974; Lahr, 1975). Hypocenter shifts due to the oversimplified flat-layer model ranged from near zero at a depth of $60 \mathrm{~km}$ to as great as $25 \mathrm{~km}$ at 160-km depth. The offsets were oriented in such a way that the dip of the Wadati-Benioff zone would appear to be too great for locations based on a flat-layered model.

The choice of which velocity model to use in calculating the traveltime from an earthquake to a given station was based on the location of the earthquake. Table 3 summarizes the assignment of starting depth, velocity model, and station delay models.

\section{Traveltime Delay Models and Trial Focal Depths}

Corrections for P-phase and S-phase traveltime delays were applied at stations in the network that have consistently large residuals for most earthquakes (Table 4). The particular correction that was used to locate an earthquake was determined by the region in which the earthquake occurs (see Table 3). 
Additional corrections were applied at several stations to correct for telemetry delays associated with one or more satellite hops ( $0.27 \mathrm{~s}$ transmission delay per hop) used in the telephone relay of the signal and were kept updated in the station-history data base.

Because the depths of earthquakes in southern Alaska range from the surface to almost 200 $\mathrm{km}$, hypocenters were computed starting at several trial focal depths to find the best solution. First, fixed-depth solutions were computed at depths $\mathrm{z}=0$ and $75 \mathrm{~km}$, and a free-depth solution starting at $\mathrm{z}=75 \mathrm{~km}$ was determined. If the latter solution had $\mathrm{z}<20 \mathrm{~km}$ and a significantly lower RMS than at $\mathrm{z}=0$, then it was taken as the final solution. If, on the other hand, the $\mathrm{z}=0$ depth had a significantly lower RMS, then a free-depth solution starting at $\mathrm{z}=0$ was used as the final solution. If neither the free-depth solution starting at $75 \mathrm{~km}$ nor the fixed-depth solution had significantly lower RMS, then the solution with the lower RMS was considered the best. Alternatively, if the free-depth solution starting at 75-km depth has $\mathrm{z}$ greater than or equal $20 \mathrm{~km}$, then a solution with $\mathrm{z}$ fixed at $7.5 \mathrm{~km}$ was computed. Of the two fixed-depth solutions at 0 and $7.5 \mathrm{~km}$, the one with lower RMS was used as a starting location for a free-depth solution. If the latter solution was within $7.5 \mathrm{~km}$ of the free solution that started at $75 \mathrm{~km}$, then the solution with the lower RMS was reported as final. If the solutions were more than $5 \mathrm{~km}$ apart, then the one with lower RMS was reported as final. In the Gulf of Alaska where the velocity structure was poorly understood and hypocenters were not well constrained all of the depths were fixed at $10 \mathrm{~km}$ (see Table 3 for the border that was used to define the Gulf of Alaska).

\section{Magnitudes}

Magnitudes are determined from either the coda duration or the maximum trace amplitude. Eaton and others (1970) approximated the local Richter magnitude, the definition of which is tied to maximum trace amplitudes recorded on standard Wood-Anderson horizontal torsion seismographs, by magnitude based on maximum trace amplitudes recorded on high-gain, high-frequency vertical seismographs, such as those operated in the Alaskan network. The amplitude magnitude, XMAG or $\mathrm{M}_{\mathrm{X}}$, used in this catalog is based on the work of Eaton and his co-workers and is given by the expression (Lee and Lahr, 1972):

$$
\mathrm{XMAG}=\log _{10} \mathrm{~A}-\mathrm{B}_{1}+\mathrm{B}_{2} \log _{10} \mathrm{D}^{2}
$$

where $\mathrm{A}$ is the equivalent maximum trace amplitude in millimeters on a standard Wood-Anderson seismograph, $\mathrm{D}$ is the hypocentral distance in kilometers, and $\mathrm{B}_{1}$ and $\mathrm{B}_{2}$ are constants. Differences in the frequency response of the two seismograph systems are accounted for in A. It is assumed, however, that there is no systematic difference between the maximum horizontal ground motion and the maximum vertical motion. The term $-\mathrm{B}_{1}+\mathrm{B}_{2} \log _{10} \mathrm{D}^{2}$ approximates Richter's $-\log _{10} \mathrm{~A}_{\mathrm{o}}$ attenuation function (Richter, 1958, p. 342), where $A_{o}$ is the trace amplitude for an earthquake of magnitude zero as a function of epicentral distance as observed for earthquakes in southern California. The constants used are $\mathrm{B}_{1}=0.15$ and $\mathrm{B}_{2}=0.08$ for $\mathrm{D}=1-200 \mathrm{~km}$, and $\mathrm{B}_{1}=3.38$ and $\mathrm{B}_{2}$ $=1.50$ for $\mathrm{D}=200-600 \mathrm{~km}$. These constants have not been calibrated for southern coastal Alaska. 
Coda durations are also used for determining magnitude because the maximum trace amplitude is often off scale due to the limited dynamic range of the film recording. For small, shallow earthquakes in central California, Lee and others (1972) express the duration magnitude, FMAG or $M_{D}$ at a given station by the relation:

$$
\mathrm{FMAG}=-0.87+2.00 \log _{10} \mathrm{~T}+0.0035 \mathrm{~d}
$$

where $\mathrm{T}$ is the signal duration in seconds from the $\mathrm{P}$-wave onset to the point on the Develocorder film where the peak-to-peak trace amplitude of the coda envelope measured on a film viewer with 20X magnification falls below $1 \mathrm{~cm}$ ( $\mathrm{F}$ time), and $\mathrm{d}$ is the epicentral distance in kilometers.

Comparison of XMAG and FMAG estimates from equations (1) and (2) for 77 southern Alaskan shocks in the depth range 0 to $150 \mathrm{~km}$ and in the magnitude range 1.5 to 3.5 reveals a systematic linear decrease of FMAG relative to XMAG with increasing focal depth. However, no systematic dependence of $\mathrm{T}$ on $\mathrm{D}$ has been found. The following equation, including a linear depthdependence term but not a distance term, is therefore used for Alaska:

$$
\mathrm{FMAG}=-1.15+2.00 \log _{10} \mathrm{~T}+0.007 \mathrm{Z}
$$

where $\mathrm{Z}$ is the focal depth in kilometers.

The coda duration magnitudes calculated from the network data are systematically less than the magnitudes reported in the Earthquake Data File (EDF) of NOAA (Lahr and Stephens, 1983). Based on a preliminary analysis (John Lahr, unpublished data), the empirical relationship between body-wave magnitude $\mathrm{m}_{\mathrm{b}}$ and duration magnitude, $\mathrm{M}_{\mathrm{D}}$ is:

$$
\mathrm{m}_{\mathrm{b}}=1.4 \mathrm{M}_{\mathrm{D}}-0.39
$$

The magnitude preferentially assigned to each earthquake in this catalog is the mean of the FMAG (equation 3) estimates obtained for USGS stations. When no FMAG can be determined, the mean of the XMAG (equation 1) estimates for USGS stations is reported. For some earthquakes no XMAG or FMAG estimates are available and a magnitude calculated by another organization is used when available. Earthquakes with published magnitudes such as mb, Ms, or Mw greater than 5 were preferentially used instead of FMAG when no XMAG was available.

\section{Analysis of Hypocentral Quality}

Two types of errors enter into the determination of hypocenters: systematic errors limiting the accuracy and random errors limiting the precision. Systematic errors result mainly from incorrect modeling of the seismic velocity structure in the earth and from incorrect phase identification. Random errors arise primarily from timing errors; their effect on the solution for each earthquake can be estimated through the use of standard statistical techniques. 
The HYPOELLIPSE computer program determines hypocenters by minimizing differences between observed and computed traveltimes through an iterative least-squares process. For each earthquake, HYPOELLIPSE calculates the lengths and orientations of the principal axes of the joint confidence ellipsoid. The one-standard-deviation confidence ellipsoid describes the region of space within which one is 68 percent confident that the hypocenter lies, assuming that the only source of error is random reading errors. The confidence ellipsoid is a function of the geometry of the stations recording a particular event, the velocity model assumed, and the standard error of the arrival times; it is a measure of the precision of the hypocentral solution (see Figure 10). Repeated readings of the same phases by four seismologists have established that the standard deviation is as small as 0.01 to $0.02 \mathrm{~s}$ for the most impulsive arrivals and as large as 0.10 to $0.20 \mathrm{~s}$ for emergent arrivals. The confidence ellipsoids are computed for a standard deviation of $0.1 \mathrm{~s}$ and therefore likely overestimate the 68 percent confidence regions. The standard deviation of the residuals for an individual solution is not used to calculate the confidence ellipsoid because it contains information not only about random reading errors but also about the incompatibility of the velocity model to the data.

In a few extreme cases the value calculated for one of the ellipsoid axes becomes very large corresponding to a spatial direction with very great uncertainty. In these cases an upperbound length of $50 \mathrm{~km}$ is tabulated. In most hypocentral solutions, the epicentral precision (SEH) is better determined than the focal depth precision (SEZ) so that SEH is generally smaller than SEZ.

To fully evaluate the quality of a hypocenter one must consider both the size and orientation of the confidence ellipsoid and the root-mean-square (RMS) residual (see description of RMS in Section 2.3.4 in HYPOELLIPSE manuel). In addition to reflecting random errors, the RMS residual can be large due to the misfit of the velocity model to the actual velocities within the earth, misinterpretation of phases, and systematic timing errors. In areas where the velocity structure is accurately known, a large RMS residual would probably indicate errors in the phase data. If the assumed velocity model does not represent the true seismic velocity structure within the earth, the RMS residuals could be large and reflect the incompatibility; alternatively, the RMS residuals could be small and not indicate the actual error in a mislocated hypocenter.

Other parameters provided by HYPOELLIPSE that are helpful in evaluating the quality of a hypocentral solution are: 1) GAP, the largest azimuthal separation between stations measured in degrees at the epicenter. If GAP exceeds $180^{\circ}$, the earthquake lies outside the network of stations used to locate the shock, and the solution is generally less reliable than that for an event occurring inside the network. 2) D1, the epicentral distance in kilometers of the closest station used in the solution. Solutions where the calculated depth is greater than D1 generally have smaller SEZ values (better depth precision) than events that have calculated depths less than the epicentral distance to the closest station. 3) NP and NS, the number of P- and S-arrivals, respectively, used in the solution. The accuracy of the solutions generally improves with an increase in the number of $\mathrm{P}$ and S-arrivals. The RMS residual may actually increase, however, if distant stations are included in locating an event, because the differences between the observed and calculated traveltimes commonly increase with increasing epicentral distance due to the errors in the assumed velocity model. 


\section{Hypocenter Precision}

The precision of the hypocenters, or the relative location accuracy of neighboring events, is represented by the confidence ellipsoids. The precision of epicenters, expressed in terms of the maximum semi-axis of the projected one-standard-deviation confidence ellipsoid (SEH), averages $4.4,1.7$, and $1.9 \mathrm{~km}$, respectively, in the eastern (east of longitude $145^{\circ} \mathrm{W}$.), central (between longitudes $145^{\circ} \mathrm{E}$ and $150^{\circ} \mathrm{W}$.) and western (west of longitude $150^{\circ} \mathrm{W}$.) parts of the network. Similarly, the precision of focal depth (SEZ) averages about 4.7, 3.0 and $3.3 \mathrm{~km}$, respectively. The variation in the precision of hypocenter determination across the network is strongly influenced by differences in the station density in the different regions. Hypocenter biases equal to and larger than the dimensions of the confidence ellipsoids are not unlikely as a consequence of the over-simplified velocity models assumed in the preparation of this catalog.

\section{Focal Depths}

Previous studies (e.g., Francis and others, 1978; Lilwall and Francis, 1978; Uhrhammer, 1980; and McLaren and Frohlich, 1985) have shown that the accuracy of focal depths for shocks occurring in the vicinity of a seismic network is primarily a function of the geometry of the network, the number of P- and S-phase arrivals read, and the adequacy of the assumed velocity

model. Depths are generally more accurate for earthquakes where the distance from the epicenter to the closest station (D1) is less than the calculated focal depth used for events located within the network or on its periphery. The accuracy of focal depths usually increases as the number of Sphase arrivals increases; however, systematic S-phase timing errors (due to mistaken identification of a converted phase as S) or "bad" S picks can degrade focal depth estimation accuracy by several kilometers even when azimuthal coverage is good (Gomberg and others, 1990). Focal depths for shallow (depth less than about 20-30 km) shocks within the southern Alaska network generally are not well constrained due to the relatively large distances between stations and to a lack of knowledge about the velocity structure. Calculated depths for the same event can vary by several kilometers depending on the number of P-and S-phase arrivals used in the location, the trial focal depth, the velocity model, and the P-phase traveltime corrections used to locate the earthquake. Ambiguity in the calculated depth occasionally arises in cases where the traveltimes to receiving stations are similar for upward-leaving rays from a deep source and for downward-leaving rays from a shallow source; this situation leads to double minima in the variation of RMS residuals with depths and is common for events outside the boundaries of the network.

\section{Completeness of Catalog}

The magnitude threshold at which this catalog is complete varies geographically as a function of the density of stations and the criteria for timing earthquakes (see section on Data Processing and Appendix C). This catalog contains an early time period for which the seismic data collected by the project were not processed:

November and December 1971

January, February 1-21, and March 2-18, 1972 
The most thorough error checking was completed for time periods with published catalogs (Appendix B) and for data processed since 1981. First order quality control checks were made to the catalog for the time periods before 1981 .

For some time periods, data from published catalogs from the National Earthquake Information Center (NEIC), the International Seismological Centre (ISC), and/or the Pacific Geoscience Center (PGC) were added to this catalog to improve hypocenter solutions, to facilitate reviews of the seismicity, and to improve the magnitude threshold for completeness. These data typically were added to Alaska network data, and the combined data were rerun with the same velocity models used in routine processing. Some regional events not located by the authors also were included, with hypocenter solutions and phase data taken from other published catalogs.

\section{Seismicity of Southern Alaska}

Reviews of the seismicity of the Aleutian arc, continental Alaska, and western Canada have been written by Taber and others (1991), Page and others (1991), and Rogers and Horner (1991), respectively. Meyers (1976) and Espinosa (1984) reviewed teleseismically-recorded earthquakes in Alaska. The purpose of this section is to discuss briefly the distribution of the seismicity within southern Alaska for over 53,000 earthquakes and other events recorded and located by the USGS seismograph network in southern Alaska for October 1971 to May 1989, and to cite the published literature written by the authors. No attempts were made to remove artillery, quarry and mine blasts or glacial quakes from the data set. The gross features of the pattern of seismicity in southern Alaska are shown in Figures 5-9.

The oceanic Pacific plate is being subducted beneath the continental North American plate (Alaska) along the Aleutian megathrust, which crops out on the seafloor at the Aleutian trench (Figure 1). The seismicity related to various tectonic elements can be divided into five distinct source zones as follows: 1) Aleutian megathrust earthquakes along the interface between the subducting Pacific plate and the overriding North American plate; 2) subsea earthquakes within the Pacific plate beneath or seaward of the trench; 3) Wadati-Benioff Zone (WBZ) earthquakes within the subducted part of the Pacific plate landward of the trench; 4) overriding plate earthquakes in the North American plate exclusive of those along the volcanic arc; and 5) volcanic axis earthquakes within the North American plate along the axis of active volcanoes.

\section{Aleutian megathrust earthquakes}

Historically, most of the seismic energy in southern Alaska is released in major earthquakes that rupture the shallow part of the dipping thrust between the subducting and overriding plates. In September 1899 a pair of moment magnitude $\left(\mathrm{M}_{\mathrm{W}}\right) 8.1$ shocks ruptured the transitional segment between Yakutat Bay and Kayak Island (McCann and others, 1980). In 1964 the convergent plate boundary west of Kayak Island slipped approximately $15 \mathrm{~m}$ in a $\mathrm{M}_{\mathrm{W}} 9.2$ earthquake (Plafker, 1969; Hastie and Savage, 1970), the second largest earthquake of the twentieth century worldwide.

Beneath a certain depth, estimated to be about $40 \mathrm{~km}$ in the Aleutian arc (Davies and House, 1979) and about $20 \mathrm{~km}$ in the northern Prince William Sound region (Page and others, 1989), the interface slips aseismically. 
The coastal region from about Kayak Island to Yakutat Bay had been identified by the early 1970's as a seismic gap due to the lack of significant shocks since the turn of the century (Tobin and Sykes, 1968; Kelleher, 1970; Sykes, 1971). In 1979, the $\mathrm{M}_{\mathrm{S}} 7.1$ St. Elias earthquake (Figure 5) occurred at the eastern end of this gap and involved low-angle, north-northwest-directed thrusting (Hasegawa and others, 1980) at depths between 10-15 km (Stephens and others, 1980) in a zone that at least locally is no more than 2-3 km thick (Page and others, 1984). The Yakataga seismic gap, which extends westward from the western limit of the St. Elias aftershock zone to the eastern extent of the 1964 rupture, is considered a likely site for a great $\left(\mathrm{M}_{\mathrm{S}} 7.8\right.$ or greater $)$ thrust earthquake within the next few decades (McCann and others, 1980; Lahr and others, 1980; Jacob, 1984; Stephens and others, 1992).

Seismicity of the gap region has been monitored nearly continuously since 1974 when the network was extended across this region. East of longitude $145^{\circ} \mathrm{W}$, the apparent high rate of shallow activity is due at least in part to a lower magnitude threshold used in selecting events for processing. During this period the spatial distribution of seismicity landward of the continental margin has remained relatively stable and is characterized by broad concentrations of shallow seismicity (depths less than $30 \mathrm{~km}$ ) beneath Icy Bay, Waxell Ridge, and the Copper River delta separated by areas of relative quiescence with most of the shocks occurring in a zone that extends about $90 \mathrm{~km}$ inland from the coast (Figure 7 and Figure 9, section D). The most active area has been the aftershock zone of the St. Elias earthquake, both prior to and since the mainshock.

Hypocenters of better-recorded shocks from the diffuse patch of seismicity near Waxell Ridge at the center of the gap concentrate near a depth of $12 \mathrm{~km}$ (Stephens and others, 1992), which is comparable to the depth to the thrust plane defined by seismicity beneath the St. Elias area. The Copper River Delta seismicity on the western edge of the gap is discussed in the section on WadatiBenioff zone earthquakes. The largest earthquake located within the gap since 1971 is a $\mathrm{M}_{\mathrm{X}} 4.1$ shock on December 1980 near the southwest corner of the Waxell Ridge concentration of seismicity.

\section{Subsea earthquakes}

There is very little historical evidence of seismicity in the Gulf of Alaska seaward of the continental margin. However, in November 1987 and March 1988, two strike-slip earthquakes in the northern Gulf of Alaska with magnitudes $\mathrm{M}_{\mathrm{w}} 7.9$ and $\mathrm{M}_{\mathrm{w}} 7.8$ (respectively) ruptured a composite 250-km-long, north-striking zone in the Pacific plate (Figures 5 and 7) south of the Yakataga seismic gap (Lahr and others, 1988a). These events are thought to reflect shear stress in the Pacific plate seaward of the boundary between the locked Yakataga seismic gap and the recently slipped 1964 rupture.

\section{Wadati-Benioff zone earthquakes}

Wadati-Benioff seismic zones are associated with both the northeast-to-north-trending Aleutian volcanic arc west of Cook Inlet and the east-southeast-trending Wrangell volcanic arc east of longitude $145^{\circ} \mathrm{W}$. Below $30 \mathrm{~km}$ depth the distribution of earthquakes is dominated by activity within the Aleutian Benioff zone west and north of the Cook Inlet region (Figures 5 and 6, and Figure 9, sections C-E). This zone dips west-northwestward from $8-10^{\circ}$ beneath the Kenai Peninsula and Anchorage, and then steepens to about $65^{\circ}$ west of Cook Inlet, although the latter dip 
may be overestimated by about $10-15^{\circ}$ due to the systematic bias introduced by using a flat-layered velocity model. Beneath both the southern Kenai Peninsula and Anchorage the upper surface of this zone is at a depth of 30 to $35 \mathrm{~km}$, and beneath the volcanic arc west of Cook Inlet it is at a depth of about $100 \mathrm{~km}$. The average dip of the shallow (depth $<30 \mathrm{~km}$ ) part of the zone decreases from about $7^{\circ}$ beneath Prince William Sound (Page and others, 1991) to about $3-4^{\circ}$ beneath the continental margin. On a regional scale using only events with well-constrained focal depths, the maximum thickness of the Aleutian WBZ is about $15 \mathrm{~km}$. The zone appears to thicken slightly beneath the southern Kenai Peninsula and Anchorage. The maximum focal depth varies along the length of the zone from about $200 \mathrm{~km}$ near Iliamna (Figure 9, section E) to about $160 \mathrm{~km}$ beneath the northernmost Cook Inlet Volcano (Figure 9, section D) and to about $150 \mathrm{~km}$ beneath the Alaska Range (Figure 9, section C). Beneath continental Alaska, the Aleutian WBZ is made up of a single zone of earthquakes, in contrast to the two zones of seismicity beneath the eastern Aleutian arc near the Shumagin Islands (Taber and others, 1991). The geometry of the Aleutian WBZ changes along strike as documented in studies of both teleseismically and regionally recorded earthquakes (Van Wormer and others, 1974; Lahr, 1975; Davies, 1975; Agnew, 1980; Pulpan and Frohlich, 1985). In lower Cook Inlet near latitude $59^{\circ} \mathrm{N}$, the strike of the deep WBZ rotates $15^{\circ}$ counterclockwise (Pulpan and Frohlich, 1985), and about $350 \mathrm{~km}$ farther north the strike swings about $35^{\circ}$ clockwise (Agnew, 1980). The deeper seismicity east of the Cook Inlet region appears to be bounded by a northwest-southeast trending line, which passes about $50 \mathrm{~km}$ northeast of Valdez (Figure 6). Such a line approximately delineates the northeastern terminus of the Aleutian Benioff zone (Stephens and others, 1984a). The diffuse appearance of the Aleutian Benioff zone in Figure 9, section C, may be attributed in part to a lack of focal depth control for earthquakes north of the USGS network (north of $\left.62^{\circ} \mathrm{N}\right)$.

The magnitude of the largest shocks recorded by the network within the southern Alaska segment of the Aleutian WBZ since 1971 have been in the magnitude 6 class (Figure 5). In July and September of 1983 the two $\mathrm{M}_{\mathrm{S}} 6.3\left(\mathrm{~m}_{\mathrm{b}} 6.2\right)$ Columbia Bay shocks occurred in the shallow part of the WBZ beneath the north coast of Prince William Sound and involved normal faulting on steeply northwestward-dipping planes between depths of 22-35 km (Page and others, 1985, 1989). A $M_{X} 6.1\left(m_{b} 5.5\right)$ earthquake occurred beneath Mt. Spurr in November 1988 with a calculated depth of $138 \mathrm{~km}$. The focal mechanism for this event, using local network data, exhibits down-dip tension and along strike compression which is typical for the deep WBZ zone activity in the Cook Inlet region (Lahr, 1975; Engle, K. Y., 1982; Pulpan and Frohlich, 1985).

The rate and character of seismicity between the shallow and deep parts of the Aleutian WBZ are significantly different, with the higher level of activity in the deep part of the zone beneath the western Kenai Peninsula, Cook Inlet, and the volcanic arc. Since 1971 the distribution of seismicity generally has not been uniform and has a significant component of spatial and temporal clustering. Clustering is more common in the shallow WBZ with mainshocks followed by energetic aftershock sequences such as the aftershock sequences following the two 1983 Columbia Bay earthquakes. In contrast, few, if any, aftershocks have been recorded following WBZ shocks in the deep part. Three persistent, diffuse concentration of events not associated with an aftershock sequence are located about $40 \mathrm{~km}$ northeast, $150 \mathrm{~km}$ southeast, and $75 \mathrm{~km}$ southwest of the Columbia Bay shocks beneath the Tazlina Glacier (latitude $61^{\circ} \mathrm{N} 30^{\prime} \mathrm{N}$, longitude $146^{\circ} 35^{\prime} \mathrm{W}$ ), the Copper River Delta, and the northern end Knight Island, respectively. The Tazlina Glacier cluster 
is a north-northeast-trending swath of seismicity with depths between $25-45 \mathrm{~km}$ (Page and others, 1989). Preliminary relocations of well-recorded earthquakes in the persistent, low-magnitude seismicity beneath the Copper River Delta at the western edge of the gap occur at depths between 20-30 km and appear to occur below the megathrust based on one teleseismically recorded thrust event that occurred in 1970 with a depth of about $21 \mathrm{~km}$ (Stephens and others, 1992). The northern Knight Island source area was the focus of a special field recording effort in 1987 in which eight stations were operated for one month. Relocated hypocenters from that effort define a subhorizontal tabular zone, which is $6 \mathrm{~km}$ thick and whose upper surface is about $18 \mathrm{~km}$ deep (Lahr and others, 1988b). Spatial clustering in the deep WBZ is conspicuous (Figures 5 and 6) with concentrations of events deeper than $110 \mathrm{~km}$ beneath Mts. Iliamna and McKinley and northwest of Anchorage, while other parts are relatively quiet, such as in the vicinity of the two points $60.8^{\circ} \mathrm{N}$, $152.5^{\circ} \mathrm{W}$ and $62.5^{\circ} \mathrm{N}, 150.2^{\circ} \mathrm{W}$.

East of the Aleutian zone lies the weakly active Wrangell WBZ, which dips to the northnortheast beneath the Wrangell volcanoes (Stephens and others, 1984a; Page and others, 1989). This zone extends at least $150 \mathrm{~km}$ along strike and to depths of at least $100 \mathrm{~km}$ (Figure 6 and Figure 9, sections A and B). The Wrangell WBZ is about two orders of magnitude less active than the Aleutian zone. The largest earthquakes located in this zone by the network are a $4.5 \mathrm{~m}_{\mathrm{b}}\left(\mathrm{M}_{\mathrm{X}} 3.7\right)$ event in September 1986 at a depth of $48 \mathrm{~km}$ and a $\mathrm{M}_{\mathrm{X}} 3.7$ shock in February 1989 at a depth of 55 $\mathrm{km}$. The deepest well constrained shock is a $M_{D} 2.4$ shock in September 1986 at $97 \mathrm{~km}$ depth beneath Mt. Wrangell. The seismicity in the Aleutian and Wrangell zones appears to be continuous, at least in the depth range $20-45 \mathrm{~km}$, and may define adjacent limbs of a buckle in the subducted plate (Page and others, 1989).

\section{Overriding plate earthquakes}

Generally the distribution of shallow seismicity within the North American plate away from the volcanic axis since 1971 has been diffuse (Figure 7), and the majority of the events cannot be clearly associated with mapped fault traces. In a few cases, including the Talkeetna segment of the Castle Mountain fault, the Duke River fault near longitude $141^{\circ} \mathrm{W}$, and the northernmost segment of the Fairweather fault, earthquakes are closely associated with mapped faults. The diffuse character of the seismicity north of latitude $62.5 \mathrm{EN}$, south of latitude $59.5 \mathrm{EN}$ and east of longitude $138^{\circ} \mathrm{W}$ is at least partially attributed to these areas being outside the USGS seismograph network. The shallow seismicity does has three conspicuous concentrations: 1) a narrow zone parallel to the Duke River fault on the U.S-Canada border, 2) a diffuse north-northeast-trending band of seismicity near longitude $150^{\circ} \mathrm{W}$ extending between the Denali fault and Cook Inlet whose focal depths lie well above the Aleutian WBZ (Figure 9, section D), and 3) a band north of and parallel to the Castle Mountain fault east of longitude $151^{\circ} \mathrm{W}$. To some degree, the apparent scatter of the seismicity near the Duke River fault reflects errors in the epicenters due to uncertainties in the velocity structure and the lack of nearby seismograph stations. Recent shocks located from both regional (Horner, 1983) and local (Power, 1988b) recordings reveal that the seismicity is mostly concentrated in the vicinity of the Duke River fault.

Since 1971 the largest shallow shocks in the overriding plate have been in the magnitude 5 class (Figure 5). The August $1984 \mathrm{~m}_{\mathrm{b}}$ 5.7 Sutton earthquake ruptured a 10-km-long buried segment of the Castle Mountain fault and involved right-lateral slip on a steeply north-dipping plane (Lahr 
and others, 1986). This is the largest shock to be clearly associated with a mapped fault since the network was established. Two earthquakes, with magnitudes $\mathrm{M}_{\mathrm{X}} 5.3\left(\mathrm{~m}_{\mathrm{b}} 5.3\right)$ and $\mathrm{M}_{\mathrm{X}} 5.0\left(\mathrm{~m}_{\mathrm{b}} 4.9\right)$, occurred 3 days apart about $75 \mathrm{~km}$ northwest of Juneau and a few $\mathrm{km}$ east of the mapped trace of the Chatham Strait fault. A $m_{b} 5.7\left(M_{X}\right.$ 5.6) shock occurred in November 1987 on the Duke River fault. The $\mathrm{M}_{\mathrm{X}} 5.6\left(\mathrm{~m}_{\mathrm{b}} 4.7\right)$ shock of March 1989 was located $150 \mathrm{~km}$ west of Juneau near the entrance to Cross Sound is about $10 \mathrm{~km}$ west of the mapped trace of the Fairweather fault.

Earthquakes with reported depths of $30 \mathrm{~km}$ and deeper (Figure 6) east of longitude $145^{\circ} \mathrm{W}$ (excluding shocks beneath or more than $100 \mathrm{~km}$ southwest of the Wrangell Volcanoes), west and north of the Aleutian WBZ generally have poorly constrained focal depths and are probably in the overriding plate.

\section{Volcanic axis earthquakes}

Small, shallow earthquakes are abundant along both the Aleutian (Kienle and others, 1983; Stephens and others, 1984b) and Wrangell (Page and others, 1989) volcanic axes. The shocks recorded by the network west of Cook Inlet form a diffuse band, approximately $30 \mathrm{~km}$ wide, punctuated by pronounced clusters (Figure 7 and Figure 9, sections D and E). The volcanoes are marked by dense clusters of earthquakes shallower than $5 \mathrm{~km}$, whereas elsewhere along the Aleutian axis shocks fall in the depth range 5 to $20 \mathrm{~km}$ (Stephens and others, 1984b).

Both the 1976 and 1986 eruptions of Augustine Volcano in lower Cook Inlet were preceded and accompanied by large numbers of small earthquakes (Lalla and Kienle, 1986; Reeder and Lahr, 1987; Power, 1988). Although the earthquakes associated with these eruptions were too small to be located by the USGS network (and do not appear in the epicenter or cross section plots), the USGS stations were used to monitor activity during the 1986 eruption after all of the stations on the island had failed, possibly due to mudslides (Reeder and Lahr, 1987).

\section{Availability of Data}

The summary and corresponding archive arrival time data for over 53,000 earthquakes and other events located by the USGS southern Alaska seismograph network (Table 1) and the HYPOELLIPSE station and control files (UNIX non-Y2K version) used to locate the events are available in this report. These data also include artillery, quarry and mine blasts and glacial quakes as well as readings from teleseismic earthquakes and nuclear explosions used to check $1^{\text {st }}$ motion polarities of seismograph stations (see Table 5). Appendix B lists previously published catalogs available from the USGS Store, http://store.usgs.gov, 1-888-275-8747.

\section{Acknowledgements}

We thank the former chiefs (Howell Butler, Robert Eppley, and Tom Sokolowski) of the NOAA Tsunami Warning Center, as well as the staff and members, including Wayne Jorgensen, Alex Medbery, John Sindorf, and George Carte, for their assistance in maintaining our recording equipment in Palmer, Alaska, as well as making their seismic data available to us. 
We thank Juergen Kienle, Niren Biswas, Steve Estes, John Benevento and the staff of the Geophysical Institute of the University of Alaska for exchange of seismic data and cooperation in the operation of southern Cook Inlet seismograph stations.

We are indebted to over fifteen seismic data analysts who routinely processed the data since 1971, most of whom worked on the project for less than five years. We especially wish to thank Roy Tam who has been with the project since 1979.

We are indebted to the project's engineer, John Rogers, and all of those who have spent time fabricating, installing, and maintaining the seismograph network in Alaska, especially Mike Blackford and Ed Criley. 


\section{References}

Agnew, J.D., 1980, Seismicity of the central Alaska Range, Alaska, 1904-1978, Master's thesis, Fairbanks, University of Alaska, $88 \mathrm{p}$.

Astrue, M.C., Pelton, J.R., Lee, W.H.K., and Page, R.A., 1983, Operator's manual for a four-film computer based, sonic digitizing table to locate earthquakes, U.S. Geological Survey OpenFile Report 83-319, 40 p.

Davies, J.N., 1975, Seismological investigations of plate tectonics in south-central Alaska, Ph.D. thesis, Fairbanks, University of Alaska, 193 p.

Davies, J.N., and House, L., 1979, Aleutian subduction zone seismicity, volcano-trench separation, and their relation to great thrust-type earthquakes, Journal of Geophysical research, v. 84, p. 4583-4591.

Eaton, J.P., O'Neill, M.E., and Murdock, J.N., 1970, Aftershocks of the 1986 Parkfield-Cholame, California, earthquake: a detailed study, Bulletin of the Seismological Society of America 60, p. 1151-1197.

Engle, K.Y., 1982, earthquake focal mechanism studies of Cook Inlet area, Alaska, Master's thesis, Fairbanks, University of Alaska, $81 \mathrm{p}$.

Espinosa, A.F., 1984, Seismicity of Alaska and the Aleutian Islands, 1960-1983, U.S. Geological Survey Open-File Report 84-855, 1 over-size sheet, scale 1:12,500,000.

Fogleman, K.A., and Rogers, J.A., 1987, ELOG: Design and development of a digital earthquake recorder in study of the 1986 Talkeetna, Alaska earthquake swarm: Seismological Research Letters, Eastern Section - Seismological Society of America, v. 58, no. 1, p. 12.

Francis, T.J.G., Porter, I.T., and Lilwall, R.C., 1978, Microearthquakes near the eastern end of St. Pauls Fracture Zone, Geophysical Journal Royal Astronomical Society, v. 53, p. 201-217.

Gomberg, J.S., Shedlock, K.M., and Roecker, S.W., 1990, The effect of S-wave arrivals times on the accuracy of hypocenter estimation, Bulletin of the Seismological Society of America, v. 80 , no. 6, p. 1605-1628.

Hasegawa, H.S., Lahr, J.C. and Stephens, C.D., 1980, Fault parameters of the St. Elias, Alaska, earthquake of February 28, 1979, Bulletin of the Seismological Society of America, v. 70, no. 5, p. 1651-1660.

Hastie, L.M., and Savage, J.C., 1970, A dislocation model for the 1964 Alaska earthquake, Bulletin of the Seismological Society of America, v. 60, p. 1389-1392.

Horner, R.B, 1983, Seismicity in the St. Elias region of northwestern Canada and southeastern Alaska, Bulletin of the Seismological Society of America, v. 73, p. 1117-1137.

Jacob, K.H., 1972, Global tectonic implications of anomalous seismic P traveltimes from the nuclear explosion Longshot, Journal of Geophysical Research 77, p. 2556-2573.

Jacob, K.H., 1984, Estimates of long-term probabilities for future great earthquakes in the Aleutians, Geophysical Research Letters, v. 11, p. 295-298.

King, P.B., compiler, 1969, Tectonic Map of North America, U.S. Geological Survey, scale 1:5,000,000.

Kelleher, J.A., 1970, Space-time seismicity of the Alaska-Aleutian seismic zone, Journal of Geophysical research, v. 75, p. 5745-5756. 
Kienle, J., Swanson, S.E., and Pulpan, H., 1983, Magmatism and subduction in the eastern Aleutian arc, in Shimozuru, D., and Yokoyama, I., eds, Arc volcanism, Physics and tectonics, Terra Scientific Publishing Company, p. 191-224.

Lahr, J.C., 1975, Detailed seismic investigation of Pacific-North American plate interaction in southern Alaska, Ph.D. dissertation, Columbia University, $141 \mathrm{p}$.

Lahr, J.C., 1989, HYPOELLIPSE/Version 2.0: A computer program for determining local earthquake hypocentral parameters, magnitude, and first-motion pattern, U.S. Geological Survey Open-File Report 89-116, 60 p. http://pubs.usgs.gov/of/1989/0116/report.pdf

Lahr, J.C., 1999, HYPOELLIPSE: A computer program for determining local earthquake hypocentral parameters, magnitude, and first-motion pattern, (Y2K Compliant Version), U.S. Geological Survey Open-File Report 99-23, 116 p. http://pubs.usgs.gov/of/1999/ofr-990023/

Lahr, J.C., Engdahl, E.R., and Page, R.A., 1974, Locations and focal mechanisms of intermediate depth earthquakes below Cook Inlet, Alaska, EOS 55, 349 p.

Lahr, J.C., George Plafker, C.D.Stephens, K.A. Fogleman, and M.E. Blackford, 1979, Interim report on the St. Elias, Alaska earthquake of 28 February 1979, U.S. Geological Survey Open-File Report 79-670, 35 p. Also in Earthquake Engineering Research Institute Newsletter, v. 13, no. 4, p. 54-76.

Lahr, J.C., Page, R.A., Stephens, C.D., and Fogleman, K.A., 1986, Sutton, Alaska, earthquakes of 1984: Evidence for activity on the Talkeetna segment of the Castle Mountain fault system, Bulletin of the Seismological Society of America, v. 76, no. 4, p. 967-983.

Lahr, J.C., Page, R.A., Stephens, C.D., 1988a, Unusual earthquakes in the Gulf of Alaska and fragmentation of the Pacific plate, Geophysical Research Letters, v. 15, no. 13, p. 14831486.

Lahr, J.C., and Stephens, C.D., 1983, Eastern Gulf of Alaska seismicity: final reports to the National Oceanic and Atmospheric Administration for July 1, 1975 through September 30, 1981: U.S. Geological Survey Open-File Report 83-592, 48 p.

Lahr, J.C., Stephens, C.D., Hasegawa, H.S., and Boatwright, J., 1980, Alaskan seismic gap only partially filled by 28 February 1979 earthquake, Science, v. 207, p. 1351-1353.

Lahr, J.C., Stephens, C.D., Page, R.A., and Fogleman, K.A., 1988b, Alaska seismic studies, National Earthquake Hazards Reduction Program Summaries of Technical Reports, v. 25, U.S. Geological Survey Open-File Report 88-66, p. 16-24.

Lalla, D.J., and Kienle, J., 1986, Seismic and thermal precursors to the January 1976 eruption of Augustine Volcano, Alaska, abstract, Auckland, New Zealand, International Volcanological Congress, February 1986, p 251.

Lee, W.H.K., Bennett, R.E., and Meager, K.L., 1972, A method of estimating magnitude of local earthquakes from signal duration, U.S. Geological Survey Open-File Report, 28 p.

Lee, W.H.K., and Lahr, J.C., 1972, HYPO71: a computer program for determining hypocenter, magnitude, and first motion pattern of local earthquakes, U.S. Geological Survey Open-File Report, $100 \mathrm{p}$.

Lilwall, R.C., and Francis, T.J.G., 1978, Hypocentral resolution of small ocean bottom seismic networks, Geophysical Journal Royal Astronomical Society, v. 54, p. 721-728. 
Matumoto, T., and Page, R.A., 1969, Microaftershocks following the Alaska earthquake of 28 March 1964 -- Determination of hypocenters and crustal velocities in the Kenai PeninsulaPrince William Sound area, in Wood, F.J., ed., The Prince William Sound Earthquake of 1964 and Aftershocks, v. II, Parts B and C, U.S. Coast and Geodetic Survey Publication 103, U.S. Government Printing Office, Washington, D.C., p. 157-173.

McCann, W.R., Perez, O.J., and Sykes, L.R., 1980, Yakataga seismic gap, southern Alaska: Seismic history and earthquake potential: Science, v. 207, p. 1309-1314.

McLaren, J.P., and Frohlich, C., 1985, Model calculations of regional network locations for earthquakes in subduction zones, Bulletin of the Seismological Society of America, v. 75, no. 2, p. 397-413.

Meyers, H., 1976, A historical summary of earthquake epicenters in and near Alaska, NOAA Technical Memorandum EDS NGSDC-1, 57 p.

Mitronovas, W., and Isacks, B.L., 1971, Seismic velocity anomalies in the upper mantle beneath the Tonga-Kermadec island arc, Journal of Geophysical Research 76, p. 7154-7180.

Page, R.A., Hassler, M.H., Stephens, C.D., and Criley, E.E., 1984, Fault zone geometry of the 1979 St. Elias, Alaska, earthquake, in The United States Geological Survey in Alaska: Accomplishments during 1982, U.S. Geological Circular 939, p. 65-67.

Page, R.A., Stephens, C.D., Fogleman, K.A., and Maley, R.P., 1985, The Columbia Bay, Alaska, earthquakes of 1983, in Bartsch-Winkler, Susan, and Reed, K.M., eds., The United States Geological Survey in Alaska, Accomplishments during 1983, U.S. Geological Survey Circular 945, p. 80-83.

Page, R.A., Plafker, George, Fuis, G.S., Nokleberg, W.J., Ambos, E.L., Mooney, W.D., and Campbell, D.L., 1986, Accretion and subduction tectonics in the Chugach Mountains and Copper River Basin, Alaska: initial results of the Trans-Alaska Crustal Transect, Geology, v. 14, p. 501-505.

Page, R.A., Stephens, C.D., and Lahr, J.C., 1989, Seismicity of the Wrangell and Aleutian WadatiBenioff zones and the North American Plate along the Trans-Alaska Crustal Transect, Chugach Mountains and Copper river basin, southern Alaska, Journal of Geophysical Research, v. 94, p. 16059-16082.

Page, R.A., Biswas, N.N., Lahr, J.C., and Pulpan, H., 1991, Seismicity of continental Alaska, in Slemmons, D.B., Engdahl, E.R., Zoback, M.D., and Blackwell, D.D., eds., Neotectonics of North America: boulder, Colorado, Geological Society of America, Decade Map Volume 1.

Plafker, George, 1967, Geologic map of the Gulf of Alaska Tertiary Province, Alaska, U.S. Geological Survey Miscellaneous Investigations Map I-84, scale 1:500,000.

Plafker, George, 1969, Tectonics of the March 27, 1964, Alaska earthquake, U.S. Geological Survey Professional Paper 543-I, 74 p.

Power, John, 1988a, Seismicity associated with the 1986 eruption of Augustine volcano, Alaska, Master's thesis, Geophysical Institute, University of Alaska, Fairbanks, 142. p.

Power, M.A., 1988b, Mass movement, seismicity, and neotectonics in the northern St. Elias Mountains, Yukon, Master's thesis,, Edmonton, University of Alberta, 125 p.

Pulpan, H., and Frohlich, C., 1985, Geometry of the subducted plate near Kodiak Island and the lower Cook Inlet, Alaska, determined from relocated earthquake hypocenters: Bulletin of the Seismological society of America, v. 75, p. 791-810. 
Reeder, J.W., and Lahr, J.C., 1987, Seismological evidence of the 1976 eruption of Augustine volcano, Alaska, U.S. Geological Survey Bulletin 1768, v. 67, no. 44, p. 1197-1198.

Richter, C.F., 1958, Elementary Seismology, W.H. Freeman and Co., San Francisco, Calif., 768 p.

Robinson, M., 1990, Xpick user's manual v 2.7: Seismology Lab, Geophysical Institute, University of Alaska, $93 \mathrm{p}$.

Rogers, G.C., and Horner, R.B., 1991, An overview of western Canadian seismicity, in Slemmons, D.B., Engdahl, E.R., Zoback, M.D., and Blackwell, D.D., eds., Neotectonics of North America: Boulder, Colorado, Geological Society of America, Decade Map Volume 1.

Rogers, J.A., 1986, Increasing dynamic range in analog seismic data systems used in Alaska, U.S. Geological Survey Open-File Report, 86-78, 16 p.

Rogers, J.A., 1993, XDETECT version 3.18 users reference guide, U.S. Geological Survey OpenFile Report 93-261-A, 27 p.

Rogers, J.A., Maslak, S., and Lahr, J.C., 1980, A seismic electronic system with automatic calibration and crystal reference, U.S. Geological Survey Open-File Report 80-324, 130 p.

Rogers, J.A., and Lahr, J.C., 1986, An on-site seismic data recording system, U.S. Geological Survey Open-File Report 86-251, 47 p.

Stephens, C.D., Lahr, J.C., Fogleman, K.A., and Horner, R.B., 1980, The St. Elias, Alaska, earthquake of 28 February 1979: regional recording of aftershocks and short-term preearthquake seismicity, Bulletin of the Seismological Society of America, v. 70, no. 5, p. 1607-1633.

Stephens, C.D., Fogleman, K.A., Lahr, J.C., and Page, R.A., 1984a, Wrangell Benioff zone, southern Alaska, Geology, v. 12, p. 373-376.

Stephens, C.D., Lahr, J.C., and Page, R.A., 1984b, Seismicity along southern coastal Alaska, October 1981-September 1982, in Bartsch-Winkler, S., and Reed, K.M., eds., The United States Geological Survey in Alaska, Accomplishments during 1982, U.S. Geological Survey Circular 939, p. 78-82.

Stephens, C.D., Lahr, J.C., Page, R.A., and Fogleman, K.A., 1992, Recent Seismicity in and near the Yakataga seismic gap, southern Alaska, 1992, Abstract, Wadati Conference on great subduction earthquakes, Fairbanks, Alaska, 16-19 September 1992.

Stevenson, P.R., 1978, Program ISDS an interactive display for displaying and measuring seismic waves forms, U.S. Geological Survey-Open File Report 79-205, 175 p.

Sykes, L.R., 1971, Aftershock zones of great earthquakes, seismicity gaps, and earthquake prediction for Alaska and the Aleutians, Journal of Geophysical Research, v. 76, p. 80218041.

Taber, J.J., Billington, S., and Engdhal, E.R., 1991, Seismicity of the Aleutian Arc, in Slemmons, D.B., Engdahl, E.R., Zoback, M.D., and Blackwell, D.D., eds., Neotectonics of North America: Boulder, Colorado, Geological Society of America, Decade Map Volume 1.

Tobin, D.G., and Sykes, L.R., 1968, Seismicity and tectonics of the northeast Pacific Ocean, Journal of Geophysical Research, v. 73, p. 3821-3845.

Uhrhammer, R.A., 1980, Analysis of small seismographic station networks, Bulletin of the Seismological Society of America, v. 70, no. 4, p. 1369-1379.

Van Wormer, J.D., Davies, J., and Gedney, L., 1974, Seismicity and plate tectonics in south central Alaska, Bulletin of the Seismological Society of America, v. 64, p. 1467-1475. 


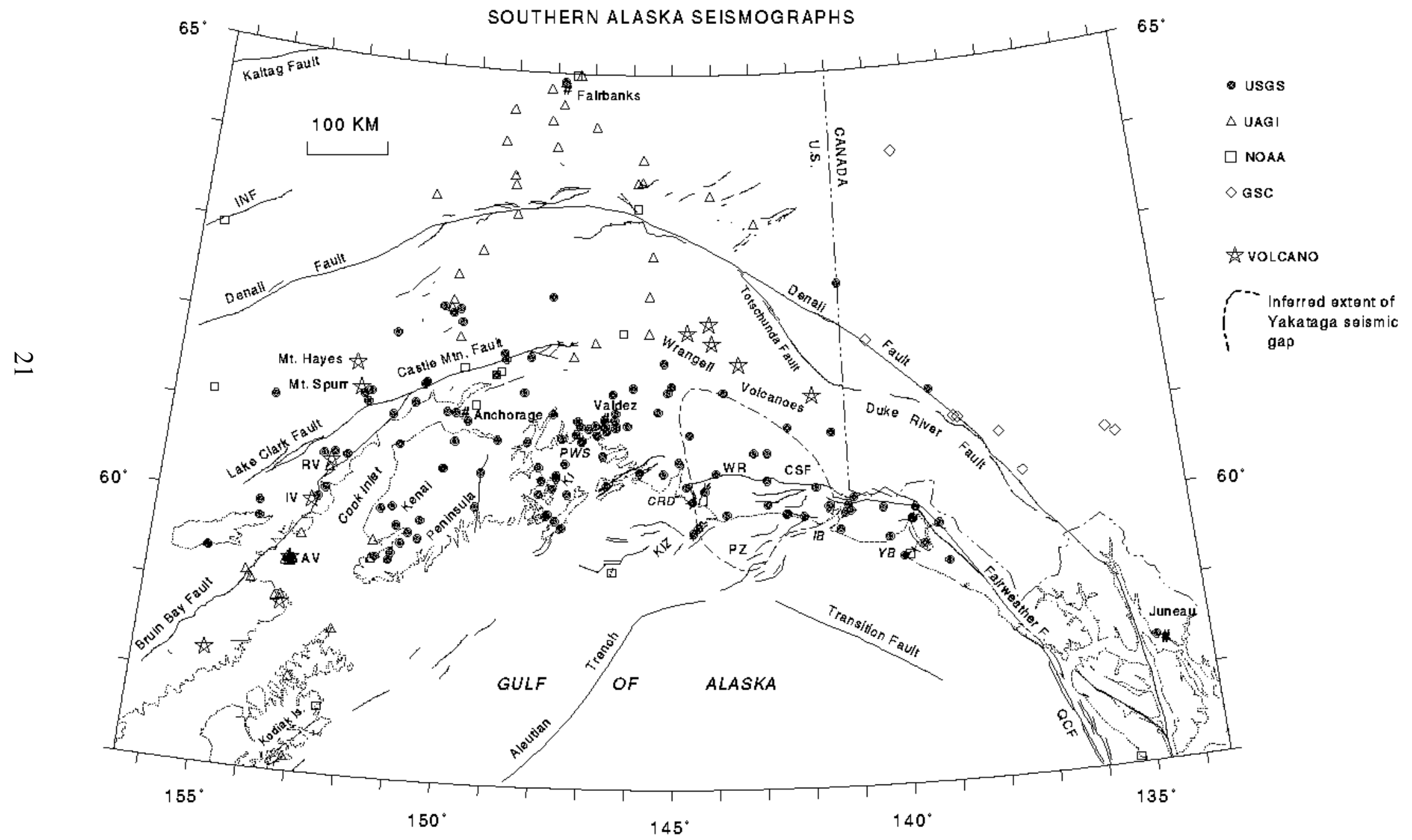

Figure 1. Map showing the locations of all USGS seismograph stations in southern Alaska along with stations operated by other institutions used in the preparation of this catalog. Neogene and younger faults (George Plafter, personal communication, 1988) are shown as solid lines. AV, Augustine volcano; CSF, Chugach-St Elias fault; CRD, Copper River Delta; IB, Icy Bay; IV, Iliamna volcano; INF, Iditarod-Nixon fault; KI, Knight Is; KIZ, Kayak Is Zone; PWS, Prince William Sound; PZ, Pamplona Zone; PWS, Prince William Sound; QCF, Queen Charlotte fault; RV, Redoubt volcano; WR, Waxell Ridge; YB, Yakutat Bay. Quaternary volcanoes are indicated by stars. 


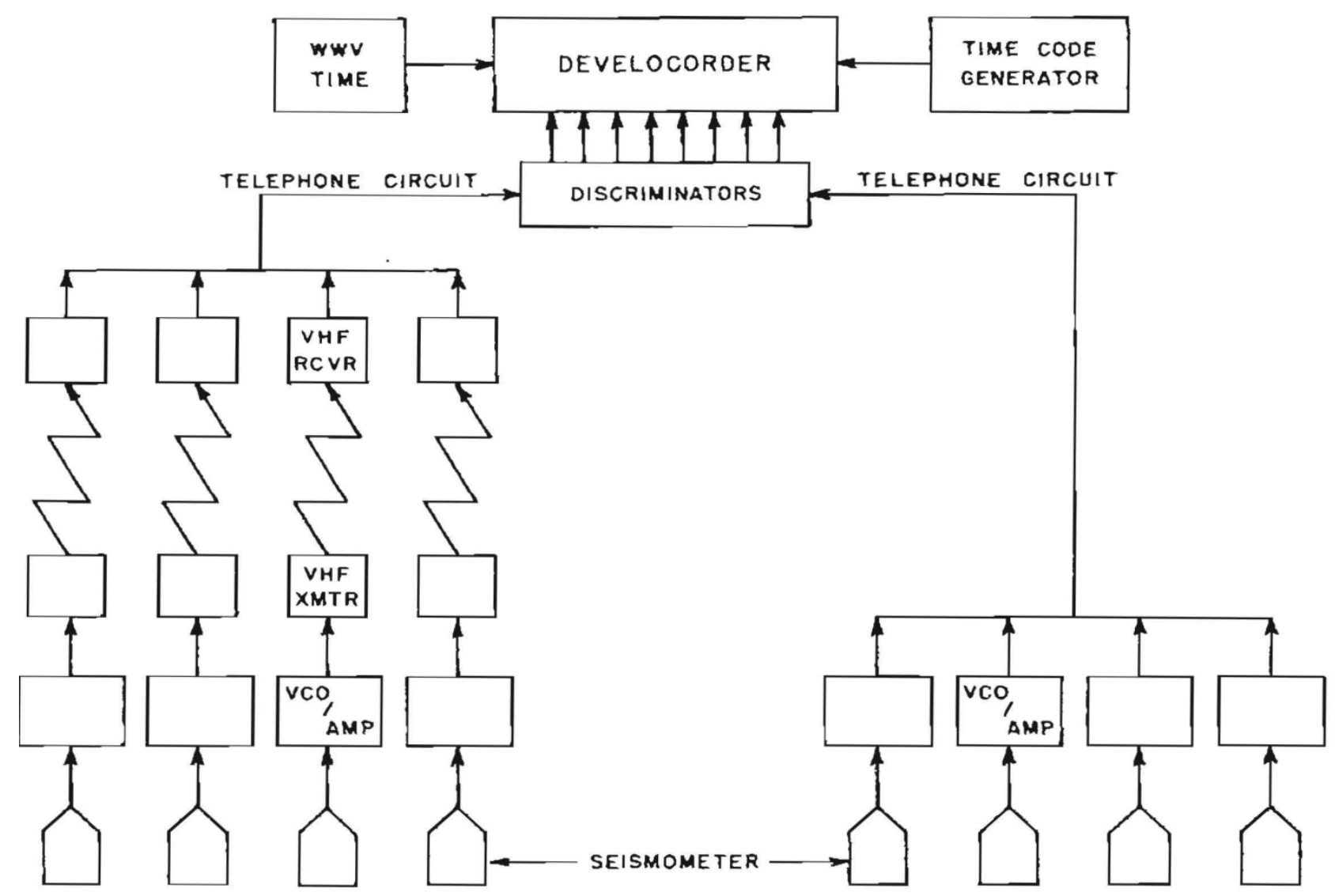

Figure 2. Block diagram of telemetered seismograph system in the USGS Alaska seismic network. 


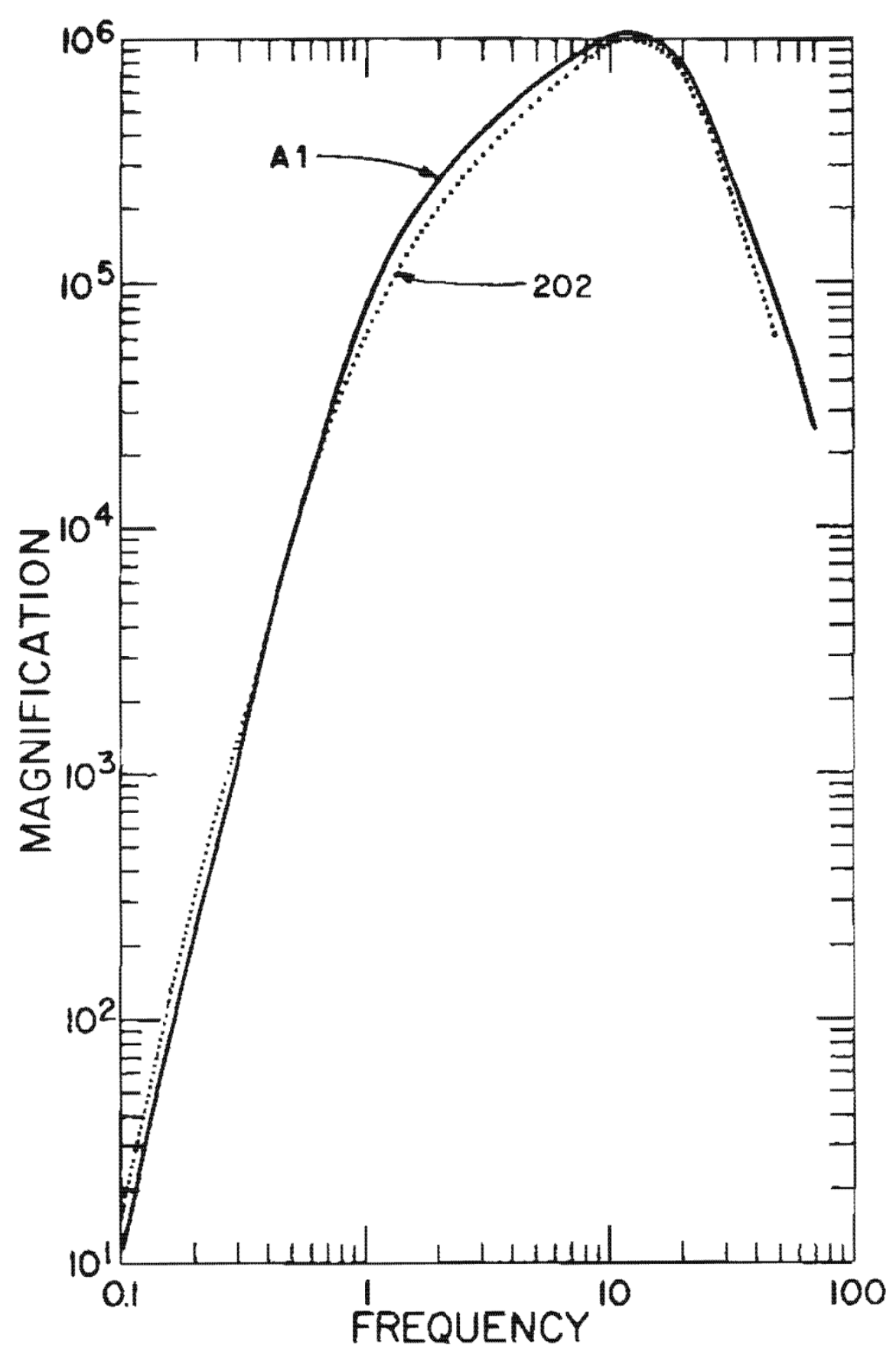

Figure 3. System response curves for typical USGS seismographs that incorporate the A1VCO unit (solid curve) and the older VCO model NCER 202 unit (dotted curve). 


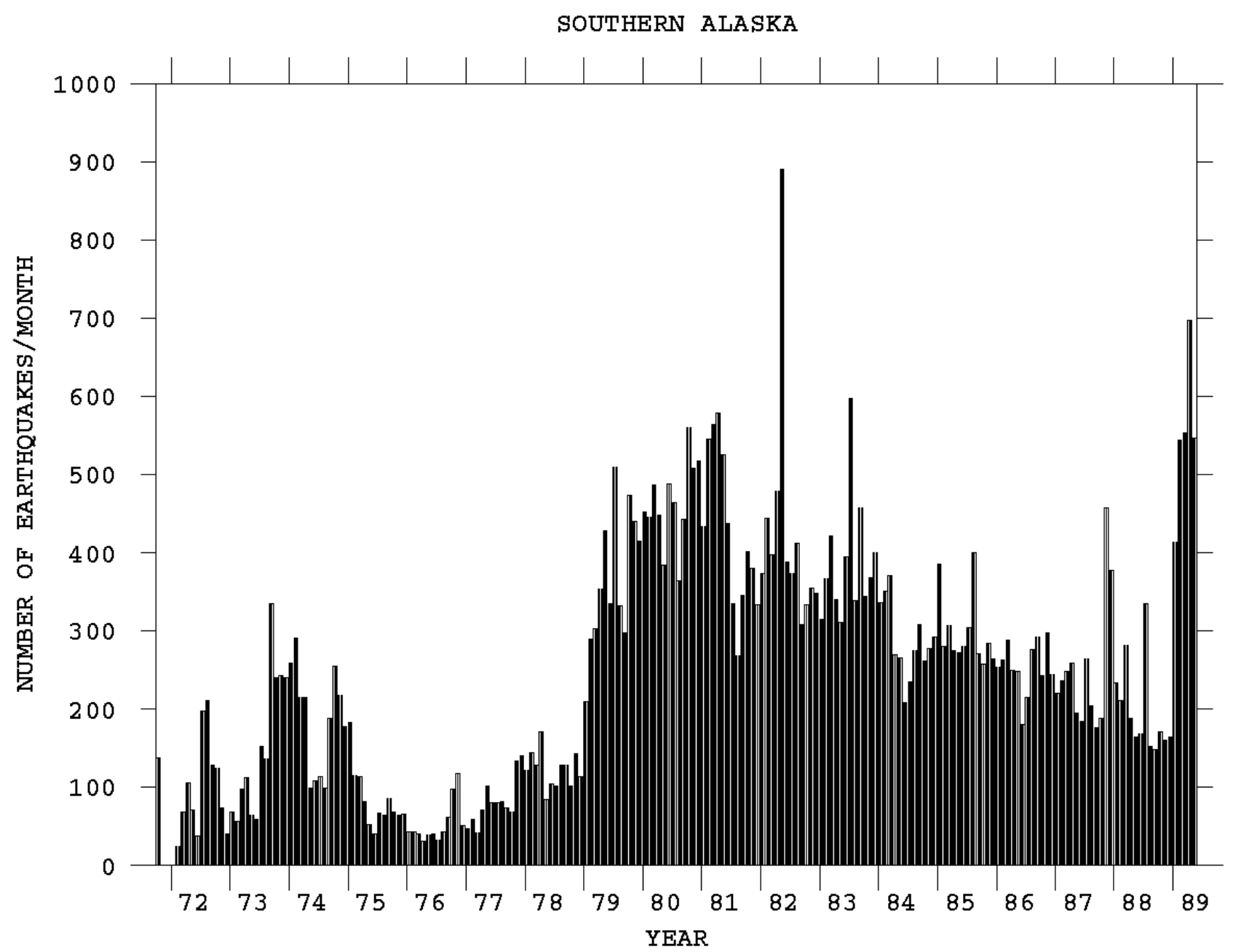

Figure 4. Histogram showing the number of earthquakes per month between October 1971 and May 1989. 
SOUTHERN ALASKA

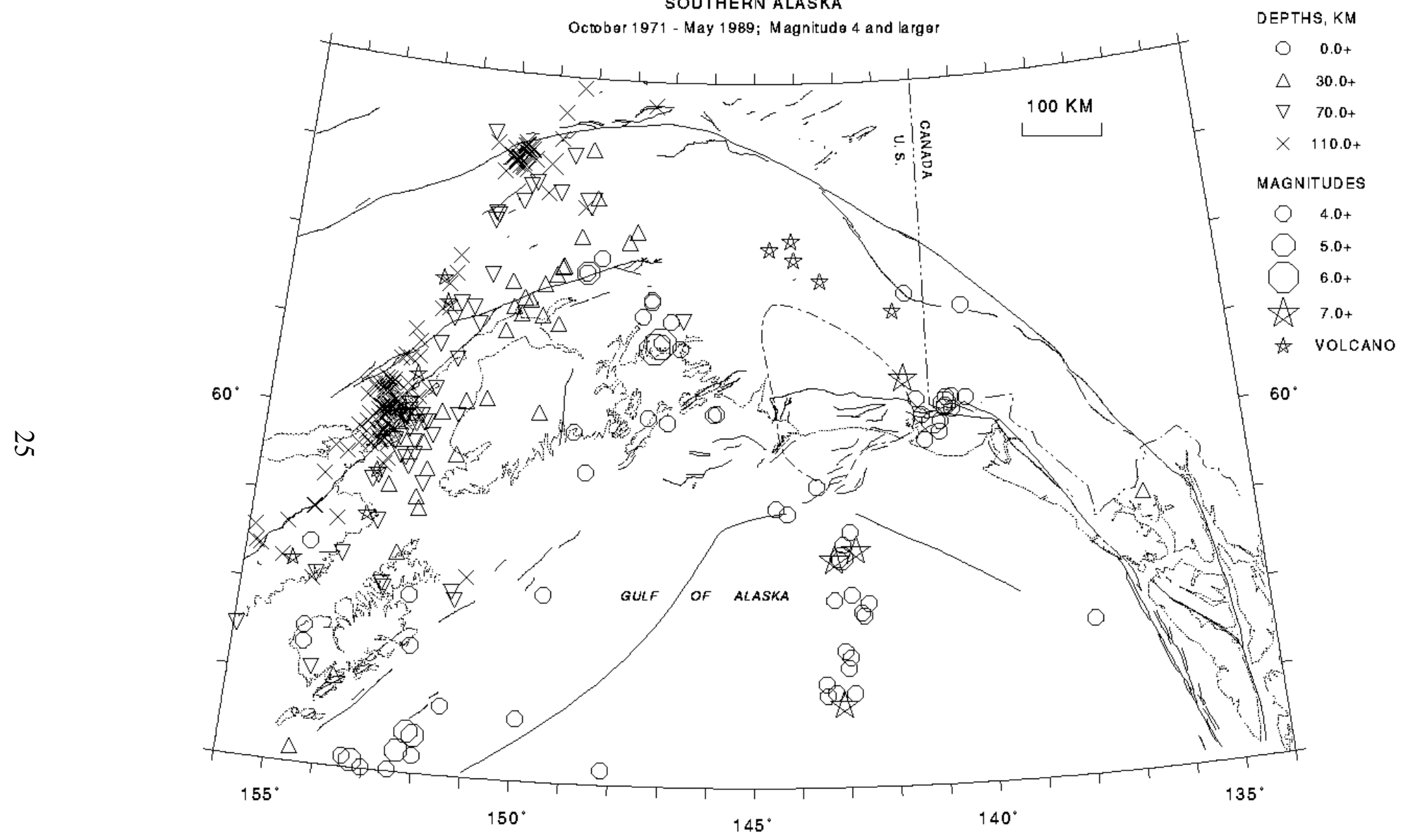

Figure 5. Epicenters of 377 earthquakes of magnitude of 4.0 or larger that occurred between October 1971 and May 1989. See Figure 1 for identification of map features. 


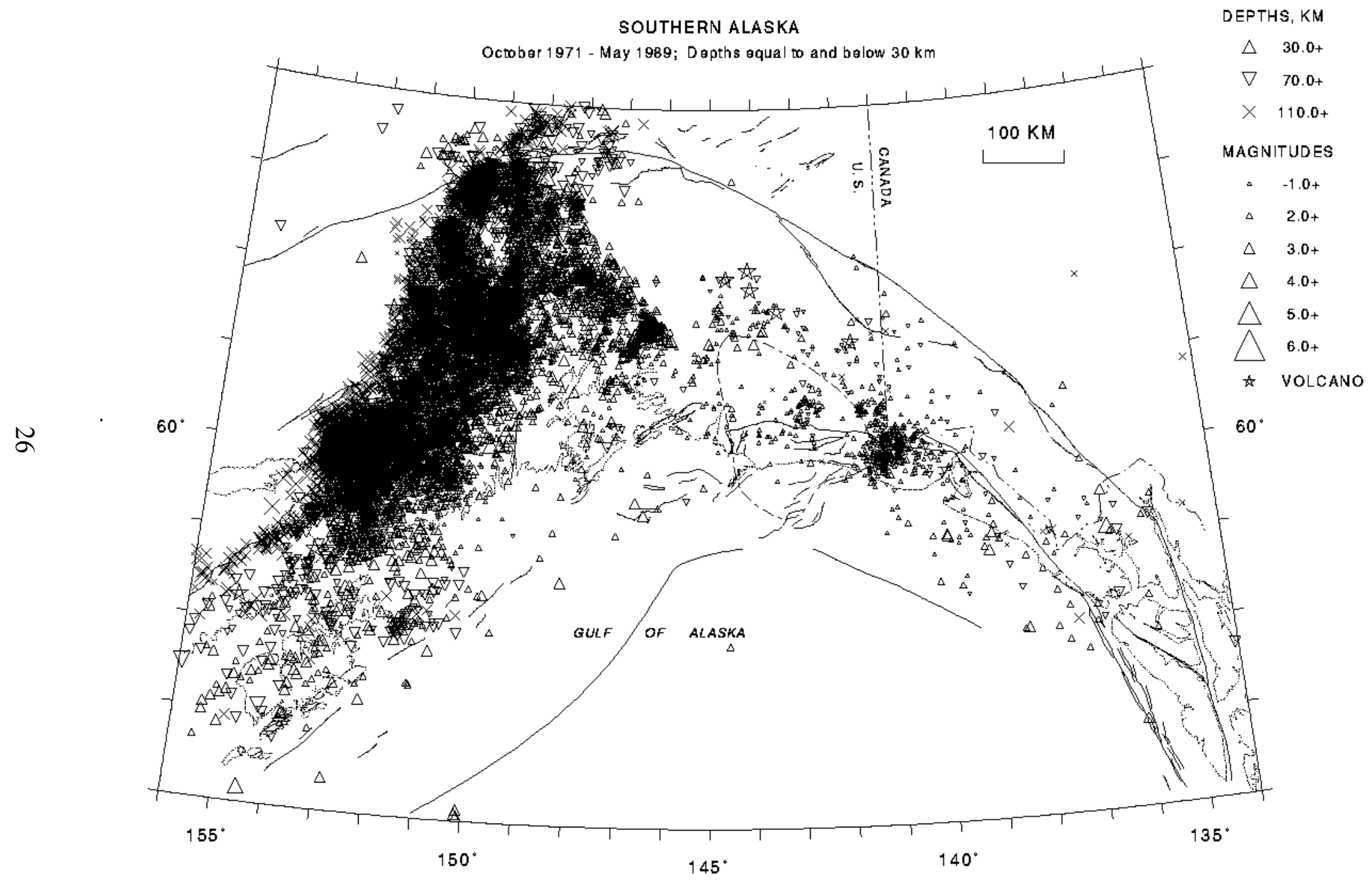

Figure 6. Epicenters of 14,884earthquakes with depths equal to or deeper than $30 \mathrm{~km}$ between October 1971 and May 1989. 
SOUTHERN ALASKA

MAGNITUDES

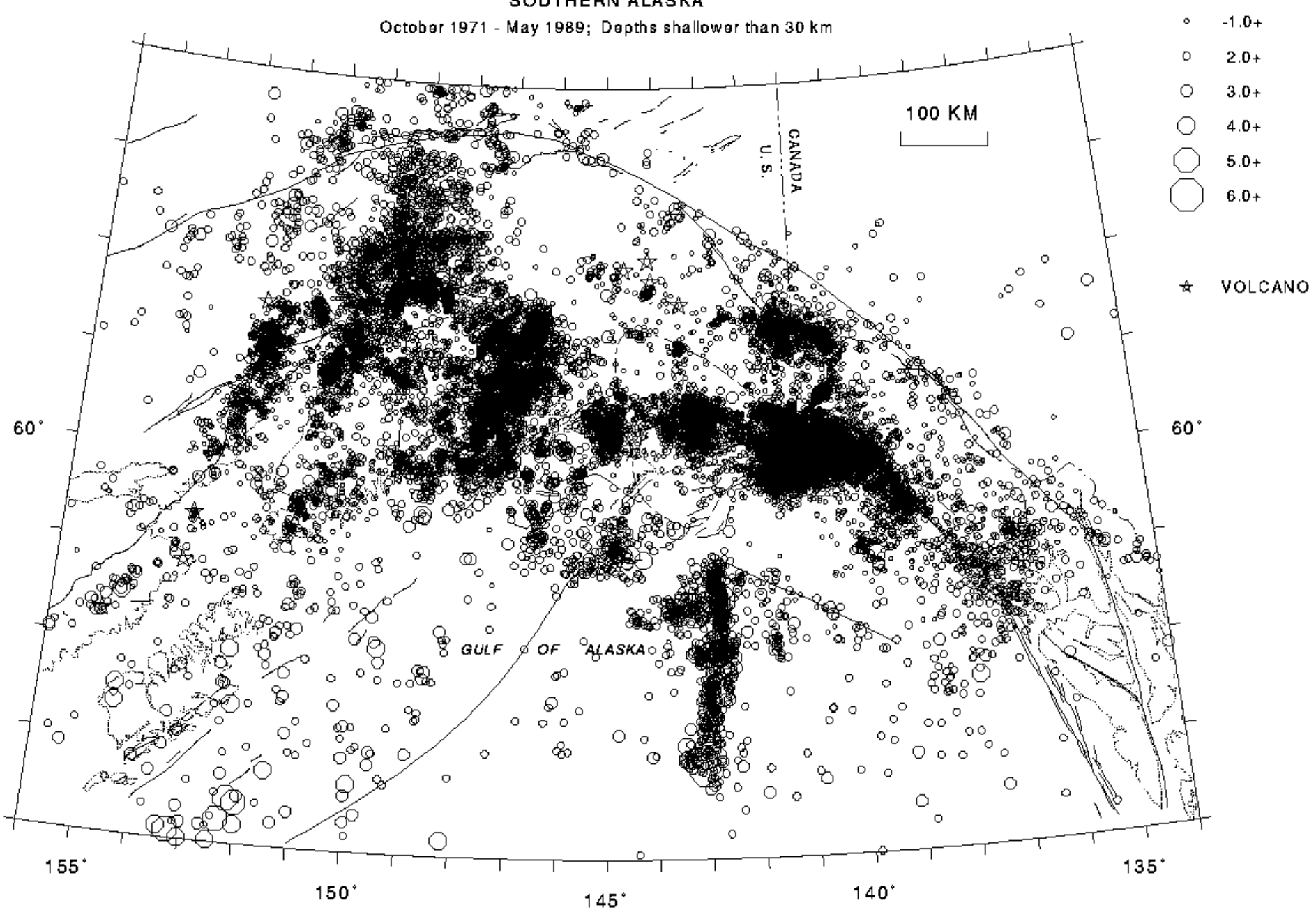

Figure 7. Epicenters of 35,225 earthquakes with depths shallower than $30 \mathrm{~km}$ between October 1971 and May 1989. 


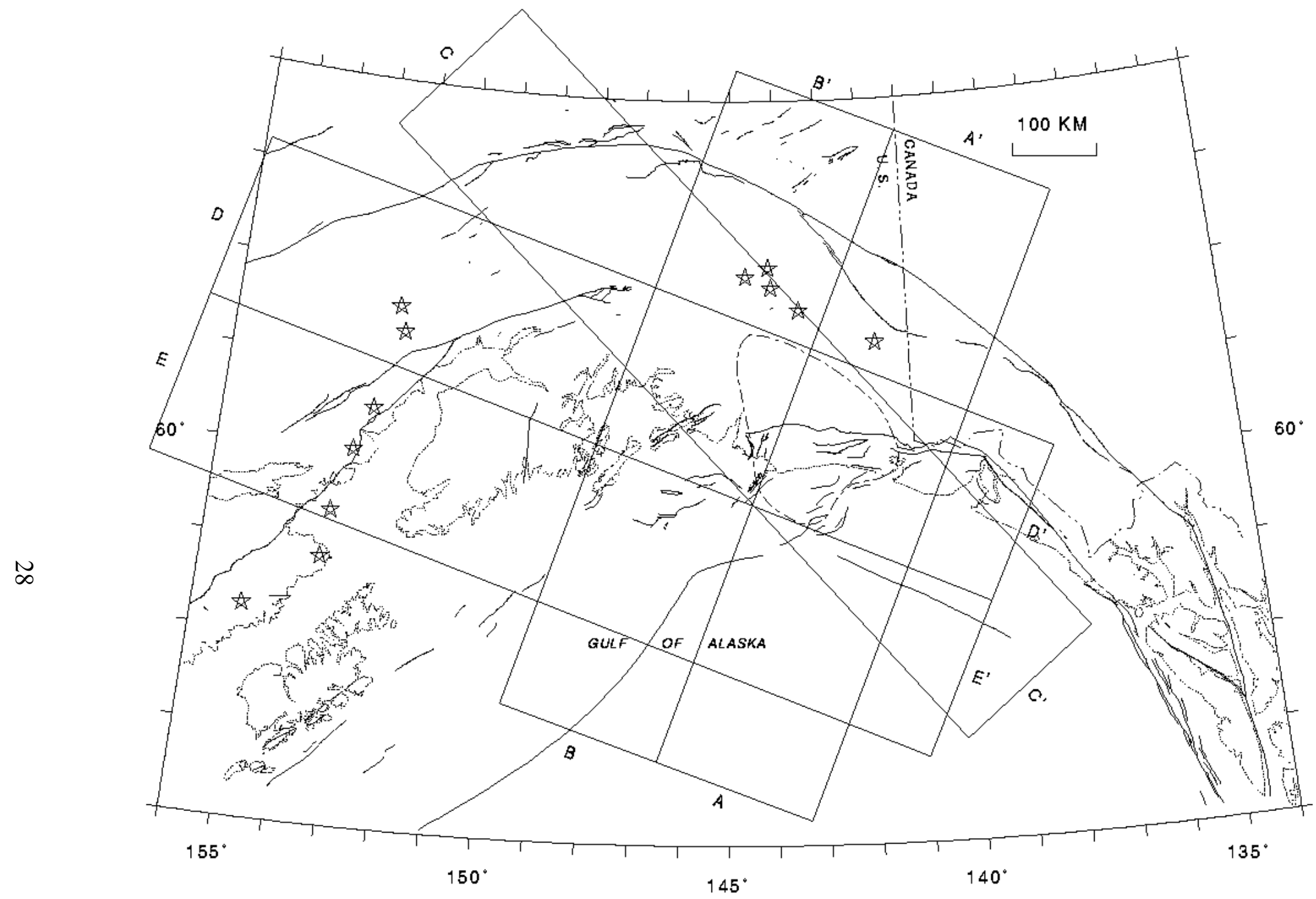

Figure 8 Reference map showing the areas represented in the cross sections in Figure 9. 

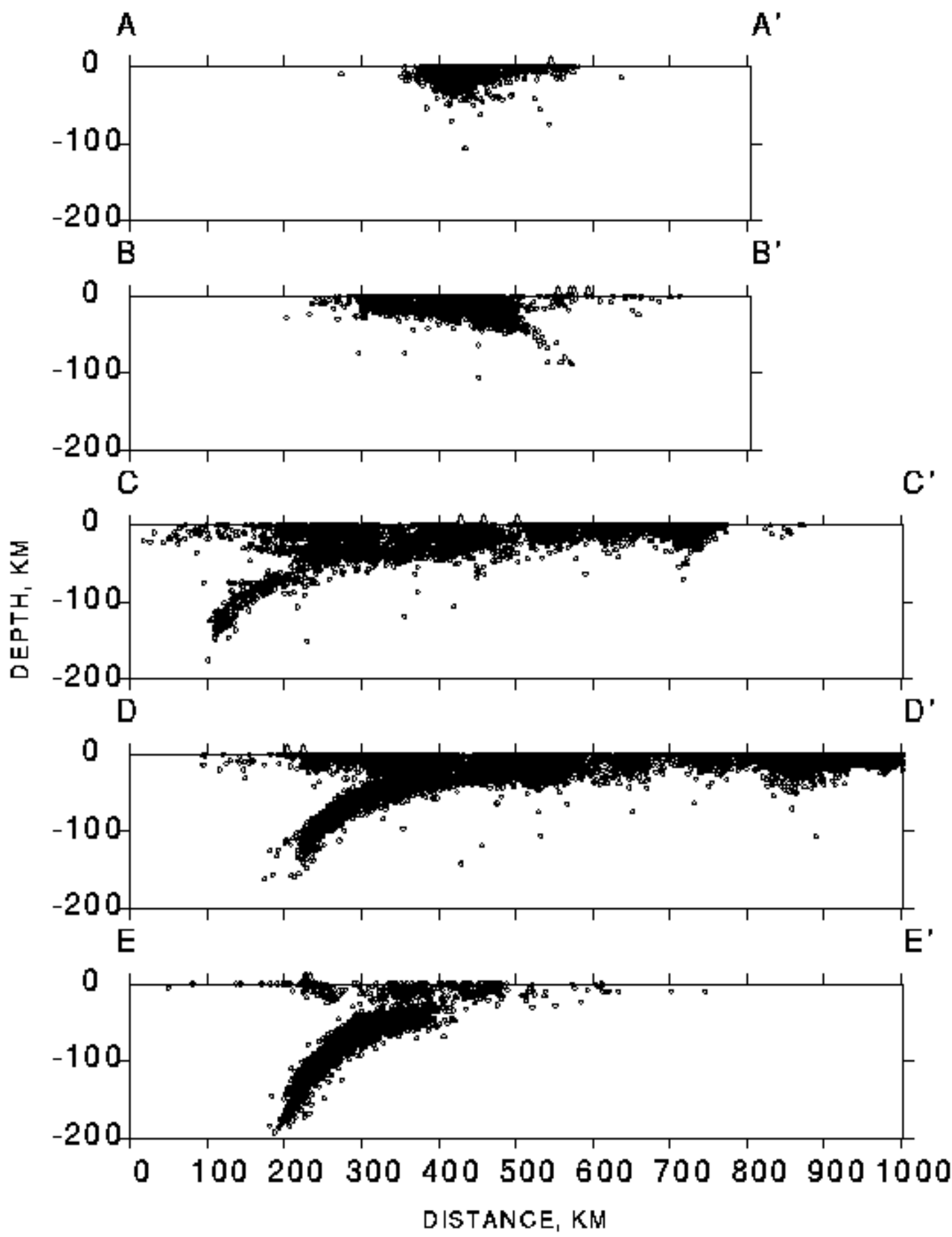

Figure 9. Sections of better-constrained hypocenters ( $\mathrm{SEH} \leq 5 \mathrm{~km}$ and $\mathrm{SEZ} \leq 10 \mathrm{~km})$ for areas indicated in Figure 8. Quaternary volcanoes plotted as triangles above zero depth. No vertical exaggeration. 


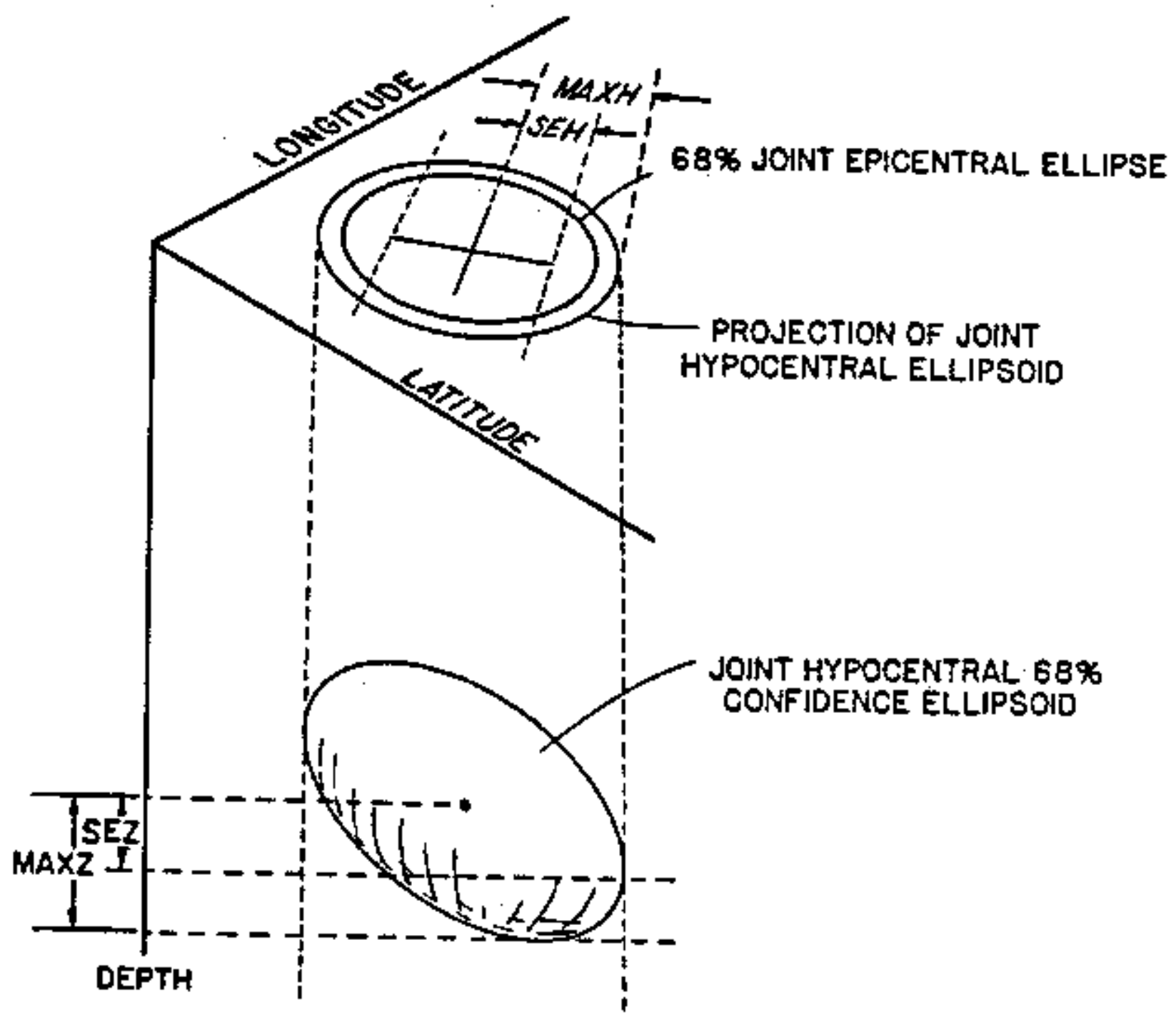

Figure 10. Relationship between the confidence ellipsoid and SEH, MAXH, SEZ, and MAXZ. The projected ellipse has the same orientation and eccentricity as the joint epicentral 68-percent confidence region, but is 1.23 times larger. The error ellipsoid is calculated assuming a constant standard deviation of $0.1 \mathrm{sec}$ for the arrival time readings. 
TABLE 1. Stations used to determine hypocenter parameters reported in this catalog. Coordinates are referenced to NAD27 Datum. INST - principal operating institution: USGS U.S. Geological Survey; UAGI - Geophysical Institute, University of Alaska; NOAA National Oceanic and Atmospheric Administration, Alaska Tsunami Warning Center, Palmer; GSC - Geological Survey of Canada, Pacific Geoscience Center (formerly Energy Mines and Resources, Canada) . Open date left blank (or $=0$ ) if unknown; closed date left blank if operation continued after May 1989. Asterisk (*) three-component site during at least part of the operation period.

\begin{tabular}{|c|c|c|c|c|c|c|c|}
\hline Code & Site Name & Latitude & Longitude & $\begin{array}{c}\text { Elev } \\
\mathrm{m}\end{array}$ & INST & Opened & Closed \\
\hline $\mathrm{ABF}$ & Auke Bay & 58.3813 & -134.6433 & 3 & USGS & $80 / 07 / 21$ & \\
\hline ADK & Adak & 51.8837 & -176.6845 & 116 & NOAA & $66 / 01 / 00$ & \\
\hline AG1 & Augustine Island & 59.3800 & -153.4200 & 580 & UAGI & $71 / 08 / 00$ & $76 / 01 / 00$ \\
\hline AGA & Agassiz Lakes & 60.1542 & -141.0333 & 1024 & USGS & $83 / 10 / 05$ & $88 / 08 / 26$ \\
\hline AGI & Augustine Island & 59.3800 & -153.4200 & 580 & UAGI & $71 / 08 / 00$ & $76 / 01 / 00$ \\
\hline ALC & Alcan & 62.6225 & -141.0083 & 582 & USGS & $79 / 10 / 25$ & $82 / 09 / 21$ \\
\hline ANM & Anvil Mountain & 64.5767 & -165.3713 & 323 & UAGI & $76 / 09 / 00$ & \\
\hline ANV & Anvil Mountain & 64.5600 & -165.3713 & 323 & UAGI & $76 / 09 / 00$ & \\
\hline AU1 & Augustine Island & 59.3732 & -153.4205 & 494 & UAGI & $71 / 08 / 00$ & $76 / 01 / 00$ \\
\hline AU2 & Augustine Island & 59.3702 & -153.3782 & 195 & UAGI & & $76 / 01 / 00$ \\
\hline AU4 & Augustine Island & 59.3360 & -153.5128 & 18 & UAGI & $76 / 01 / 00$ & $76 / 01 / 00$ \\
\hline AU5 & Augustine Island & 59.3865 & -153.4558 & 152 & UAGI & & $76 / 01 / 00$ \\
\hline AUE & Augustine East & 59.3590 & -153.3722 & 172 & UAGI & $88 / 10 / 01$ & \\
\hline AUF & Augustine Flow & 59.3878 & -153.4575 & 165 & UAGI & $77 / 07 / 28$ & $80 / 08 / 25$ \\
\hline $\mathrm{AUH}$ & Augustine Dome $\mathrm{H}$ & 59.3638 & -153.4435 & 900 & UAGI & $92 / 08 / 26$ & \\
\hline${ }^{*} \mathrm{AUI}$ & Augustine Island & 59.3352 & -153.4277 & 293 & UAGI & $78 / 01 / 01$ & \\
\hline AUK & Augustine Island & 59.3342 & -153.4270 & 293 & UAGI & $76 / 10 / 17$ & $78 / 04 / 06$ \\
\hline AUL & Augustine Lava Flow & 59.3822 & -153.4345 & 360 & UAGI & $80 / 10 / 29$ & \\
\hline AUM & Augustine Mound & 59.3710 & -153.3528 & 106 & UAGI & $75 / 09 / 00$ & $80 / 10 / 29$ \\
\hline AUP & Augustine Pinnacle & 59.3623 & -153.4205 & 1033 & UAGI & $88 / 10 / 01$ & \\
\hline AUW & Augustine West & 59.3670 & -153.4708 & 320 & UAGI & $91 / 07 / 27$ & \\
\hline BAL & Baldy & 61.0353 & -142.3472 & 1265 & USGS & $73 / 08 / 24$ & \\
\hline $\mathrm{BC} 3$ & Beaver Creek U3 & 63.0658 & -141.7827 & 848 & & & \\
\hline $\mathrm{BCP}$ & Bancas Point & 59.9533 & -139.6350 & 396 & USGS & $79 / 09 / 04$ & \\
\hline $\mathrm{BCS}$ & Bancas Point & 59.9483 & -139.6167 & 10 & USGS & $76 / 06 / 25$ & 79/09/04 \\
\hline BGA & Beluga & 61.2223 & -150.9658 & 20 & USGS & $75 / 10 / 08$ & $76 / 03 / 27$ \\
\hline BGM & Big Mountain & 59.3927 & -155.2293 & 625 & USGS & 78/09/08 & \\
\hline
\end{tabular}




\begin{tabular}{|c|c|c|c|c|c|c|c|}
\hline $\mathrm{BIG}$ & Big Mountain & 59.3890 & -155.2170 & 567 & USGS & $72 / 07 / 31$ & $78 / 09 / 08$ \\
\hline BLR & Black Rapids & 63.5017 & -145.8450 & 810 & NOAA & $65 / 03 / 00$ & $85 / 08 / 08$ \\
\hline BLY & Burwash Landing & 61.3725 & -139.0260 & 799 & USGS & $74 / 07 / 22$ & $78 / 06 / 01$ \\
\hline BMR & Bremner River & 60.9682 & -144.6030 & 823 & USGS & $79 / 08 / 19$ & $85 / 07 / 16$ \\
\hline BRW & Barrow & 71.3033 & -156.7483 & 0 & UAGI & $88 / 10 / 01$ & \\
\hline CAE & Caetani River & 60.0842 & -140.9888 & 716 & USGS & $83 / 07 / 25$ & $84 / 08 / 27$ \\
\hline $\mathrm{CCB}$ & Clear Creek Butte & 64.6467 & -147.8055 & 219 & UAGI & $83 / 09 / 16$ & \\
\hline CDA & Cape Douglas & 58.9553 & -153.5295 & 386 & UAGI & $78 / 01 / 01$ & $81 / 08 / 16$ \\
\hline CDD & Cape Douglas & 58.9298 & -153.6430 & 622 & UAGI & $81 / 08 / 17$ & \\
\hline $\mathrm{CDL}$ & Candle & 66.1140 & -161.6567 & 312 & UAGI & $78 / 12 / 16$ & \\
\hline $\mathrm{CFI}$ & College Fiord & 61.1827 & -147.7665 & 3 & USGS & $74 / 07 / 31$ & \\
\hline CGB & Congabuna & 61.0690 & -151.4525 & 160 & USGS & $75 / 10 / 08$ & $76 / 03 / 27$ \\
\hline CGL & Capps Glacier & 61.3077 & -152.0067 & 1082 & USGS & $81 / 09 / 22$ & \\
\hline $\mathrm{CHX}$ & Chaix Hills & 60.0630 & -141.1167 & 1067 & USGS & $74 / 09 / 04$ & $85 / 08 / 25$ \\
\hline CKK & Chekok Lake & 59.9597 & -154.2332 & 732 & USGS & $72 / 07 / 29$ & $78 / 09 / 09$ \\
\hline CNP & China Poot & 59.5258 & -151.2360 & 564 & USGS & $83 / 07 / 01$ & \\
\hline $\mathrm{COL}$ & College Outpost & 64.9000 & -147.7933 & 320 & USGS & $64 / 01 / 00$ & \\
\hline CRP & Crater Peak & 61.2670 & -152.1555 & 1622 & USGS & $81 / 08 / 26$ & \\
\hline CRQ & Cirque & 60.7567 & -143.1392 & 1853 & USGS & 88/07/01 & \\
\hline CSG & Childs Glacier & 60.6610 & -144.8550 & 678 & USGS & $84 / 07 / 22$ & $85 / 08 / 10$ \\
\hline CTG & Chitna Glacier & 60.9660 & -141.3383 & 1490 & USGS & $79 / 08 / 28$ & \\
\hline CUT & Chulitna & 62.4047 & -150.2695 & 168 & UAGI & 86/07/18 & \\
\hline CVA & Cordova & 60.5473 & -145.7455 & 120 & USGS & $71 / 08 / 31$ & \\
\hline CYT & Cape Yakataga & 60.0745 & -142.4113 & 323 & USGS & $78 / 08 / 08$ & $80 / 09 / 22$ \\
\hline DDM & Donnely Dome & 63.7857 & -145.8575 & 900 & UAGI & $90 / 08 / 10$ & \\
\hline DFR & Drift River & 60.5918 & -152.6860 & 1090 & USGS & $88 / 08 / 15$ & \\
\hline DLY & Dezadeash Lake & 60.3700 & -137.0650 & 738 & GSC & & \\
\hline DMA & Devil Mountain & 66.2967 & -164.5225 & 238 & UAGI & $77 / 08 / 00$ & $82 / 00 / 00$ \\
\hline DMW & Delta Microwave & 64.0538 & -145.7253 & 346 & UAGI & $86 / 00 / 0$ & $90 / 08 / 19$ \\
\hline DOT & Dot Lake & 63.6487 & -144.0625 & 671 & UAGI & $88 / 10 / 01$ & \\
\hline DSB & Disenchantment Bay & 60.0767 & -139.5450 & 640 & USGS & $74 / 09 / 08$ & 76/06/08 \\
\hline DSK & Disk Island & 60.5020 & -147.6468 & 15 & USGS & $74 / 07 / 27$ & $76 / 06 / 07$ \\
\hline DWY & Dawson City & 64.0533 & -139.4317 & 346 & GSC & & $76 / 06 / 07$ \\
\hline ERN & Ernestine & 61.4442 & -145.1123 & 570 & USGS & $71 / 09 / 16$ & $73 / 08 / 29$ \\
\hline FBA & College Outpost & 64.9000 & -147.7933 & 320 & UAGI & $91 / 08 / 01$ & \\
\hline FID & Fidalgo & 60.7288 & -146.5965 & 488 & USGS & $74 / 10 / 07$ & \\
\hline FIS & Fire Island & 61.1442 & -150.2185 & 76 & USGS & $74 / 09 / 24$ & $76 / 05 / 04$ \\
\hline FYU & Fort Yukon & 66.5660 & -145.2317 & 137 & UAGI & $88 / 10 / 01$ & \\
\hline GAR & Garner & 63.8370 & -148.9712 & 590 & UAGI & $87 / 10 / 20$ & \\
\hline
\end{tabular}




\begin{tabular}{|c|c|c|c|c|c|c|c|}
\hline GBY & Granite Bay & 60.4322 & -147.9783 & 495 & USGS & $85 / 07 / 21$ & \\
\hline $\mathrm{GHO}$ & Gloryhole & 61.7722 & -148.9242 & 1021 & USGS & $84 / 09 / 11$ & \\
\hline GIL & Gilmore Creek & 64.9750 & -147.4950 & 350 & NOAA & $67 / 10 / 13$ & \\
\hline GKC & Gold King Creek & 64.1787 & -147.9347 & 490 & UAGI & $76 / 07 / 00$ & $86 / 03 / 10$ \\
\hline${ }^{*} \mathrm{GLB}$ & Gilahina Butte & 61.4418 & -143.8105 & 845 & USGS & $73 / 08 / 25$ & \\
\hline GLC & Glacier Island & 60.8907 & -147.0730 & 3 & USGS & $72 / 07 / 24$ & $84 / 09 / 17$ \\
\hline GLI & Glacier Island & 60.8797 & -147.0942 & 429 & USGS & $84 / 09 / 17$ & \\
\hline GLM & Gilmore Dome & 64.9873 & -147.3890 & 820 & UAGI & $88 / 10 / 01$ & \\
\hline GLN & Glennallen & 62.1108 & -145.5488 & 457 & UAGI & $86 / 00 / 00$ & \\
\hline GMA & Granite Mountain & 65.4287 & -161.2320 & 858 & UAGI & $70 / 09 / 17$ & \\
\hline GYO & Guyot & 60.1463 & -141.4715 & 183 & USGS & $76 / 06 / 01$ & \\
\hline HAD & Harding Lake & 64.4057 & -146.9408 & 427 & UAGI & $77 / 09 / 00$ & \\
\hline HIN & Hinchinbrook Island & 60.3968 & -146.5017 & 611 & USGS & 74/10/03 & \\
\hline HMT & Hamilton & 60.3365 & -144.2607 & 620 & USGS & $77 / 08 / 16$ & \\
\hline HOM & Homer & 59.6583 & -151.6433 & 198 & UAGI & $81 / 01 / 01$ & \\
\hline HQN & Harlequin & 59.4517 & -138.8770 & 372 & USGS & $74 / 10 / 01$ & \\
\hline HTP & Hatcher Pass & 61.7777 & -149.2767 & 917 & UAGI & & \\
\hline HUR & Hurricane & 62.9787 & -149.6433 & 496 & UAGI & $77 / 02 / 14$ & \\
\hline HYT & Haines Junction & 60.8250 & -137.5040 & 1416 & GSC & $81 / 07 / 27$ & \\
\hline III & Iliamna & 60.0802 & -152.9595 & 823 & USGS & $87 / 09 / 15$ & \\
\hline ILM & Iliamna & 60.1820 & -152.8162 & 550 & USGS & $71 / 08 / 07$ & $87 / 09 / 16$ \\
\hline ILN & Iliamna & 60.1820 & -152.8162 & 550 & USGS & $71 / 08 / 07$ & $72 / 09 / 30$ \\
\hline IMA & Indian Mountain & 66.0685 & -153.6787 & 1380 & NOAA & $79 / 12 / 28$ & \\
\hline INK & Inuvik & 68.2917 & -133.5000 & 40 & GSC & $69 / 02 / 22$ & \\
\hline $\mathrm{KAl}$ & Kayak Island & 59.9268 & -144.4163 & 311 & USGS & $82 / 08 / 3$ & \\
\hline KDC & Kodiak & 57.7478 & -152.4917 & 13 & NOAA & $78 / 09 / 20$ & \\
\hline KEY & Kluane Lake & 61.0500 & -138.5017 & 785 & GSC & $78 / 08 / 26$ & $81 / 07 / 25$ \\
\hline KLU & Klutina & 61.4928 & -145.9202 & 1021 & USGS & $72 / 07 / 22$ & \\
\hline KMP & Kimball Pass & 61.5130 & -145.0182 & 1143 & USGS & $76 / 08 / 01$ & $85 / 07 / 19$ \\
\hline $\mathrm{KNI}$ & Knight Island & 60.3487 & -147.7360 & 434 & USGS & $85 / 07 / 21$ & \\
\hline KNK & Knik Glacier & 61.4125 & -148.4557 & 595 & USGS & $73 / 08 / 11$ & \\
\hline KRY & Koidern River & 61.9700 & -140.4083 & 686 & GSC & $78 / 08 / 29$ & $81 / 04 / 01$ \\
\hline KTA & Kotzebue & 66.8413 & -162.5870 & 24 & UAGI & 76/09/08 & $82 / 00 / 00$ \\
\hline KTH & Kantishna Hills & 63.5532 & -150.9210 & 1172 & UAGI & $88 / 10 / 01$ & \\
\hline KTM & Katmai & 58.3247 & -155.3765 & 945 & USGS & $73 / 07 / 27$ & $75 / 08 / 24$ \\
\hline KYK & Kayak Island & 59.8683 & -144.5232 & 375 & USGS & $74 / 10 / 02$ & $82 / 08 / 02$ \\
\hline LOU & Louis Bay & 60.4655 & -147.6443 & 490 & USGS & $85 / 07 / 15$ & \\
\hline LTI & Latouche Island & 60.0405 & -147.8542 & 302 & USGS & $88 / 07 / 01$ & \\
\hline LVY & Levy & 64.2167 & -149.2533 & 230 & UAGI & $72 / 07 / 0$ & $89 / 09 / 19$ \\
\hline
\end{tabular}




\begin{tabular}{|c|c|c|c|c|c|c|c|}
\hline $\mathrm{MBC}$ & Mould Bay & 76.2417 & -119.3600 & 15 & GSC & $61 / 10 / 18$ & \\
\hline MCK & Mckinley Park & 63.7323 & -148.9350 & 618 & UAGI & $64 / 00 / 00$ & \\
\hline $\mathrm{MCN}$ & Mcneil River & 59.1010 & -154.1998 & 273 & UAGI & $76 / 10 / 15$ & $81 / 08 / 22$ \\
\hline MID & Middleton Island & 59.4278 & -146.3390 & 37 & NOAA & $76 / 05 / 21$ & \\
\hline MLS & Malaspina Glacier & 59.7667 & -140.1500 & 30 & USGS & $74 / 09 / 4$ & $81 / 09 / 05$ \\
\hline MMN & Mcneil River & 59.1852 & -154.3367 & 442 & UAGI & $81 / 08 / 22$ & \\
\hline MRN & Martin River & 60.5350 & -144.0083 & 957 & USGS & $75 / 08 / 22$ & $76 / 03 / 31$ \\
\hline MSE & Moose Creek & 61.8383 & -148.9672 & 1318 & USGS & $84 / 09 / 11$ & $85 / 09 / 30$ \\
\hline MSP & Moose Pass & 60.4892 & -149.3605 & 160 & USGS & $73 / 08 / 05$ & \\
\hline MTG & Montague Island & 59.9118 & -147.4970 & 31 & USGS & $74 / 10 / 03$ & $85 / 07 / 15$ \\
\hline MTU & Montague Island & 59.9878 & -147.6503 & 434 & USGS & $85 / 07 / 21$ & \\
\hline NCA & Nelchina & 61.9937 & -146.8242 & 741 & UAGI & $86 / 07 / 17$ & $90 / 06 / 00$ \\
\hline NCT & North Cresent & 60.5632 & -152.9262 & 1079 & USGS & $88 / 08 / 14$ & \\
\hline NEA & Nenana & 64.5772 & -149.0772 & 364 & UAGI & $81 / 03 / 5$ & \\
\hline NGL & North Gasline & 60.8208 & -149.9982 & 122 & USGS & $74 / 09 / 26$ & $76 / 03 / 27$ \\
\hline NIK & Nikolski & 52.9743 & -168.8518 & 207 & NOAA & $71 / 05 / 17$ & $76 / 03 / 27$ \\
\hline NIN & Ninilchik & 60.0112 & -151.5355 & 110 & USGS & $71 / 08 / 28$ & $72 / 08 / 24$ \\
\hline${ }^{*} \mathrm{NKA}$ & Nikishka & 60.7430 & -151.2380 & 100 & USGS & $71 / 09 / 14$ & \\
\hline NKI & Nikolski & 52.9427 & -168.8575 & 8 & NOAA & $76 / 03 / 27$ & $85 / 12 / 26$ \\
\hline NNL & Ninilchik & 60.0443 & -151.2893 & 381 & USGS & $72 / 08 / 24$ & \\
\hline NRA & North River & 63.8918 & -160.5143 & 107 & UAGI & $76 / 08 / 00$ & $78 / 06 / 08$ \\
\hline NTK & Nunitak & 59.8777 & -139.0352 & 1050 & USGS & 74/09/09 & $76 / 05 / 31$ \\
\hline $\mathrm{OCC}$ & Ocean Cape & 59.5425 & -139.8602 & 22 & USGS & $76 / 01 / 01$ & $76 / 04 / 24$ \\
\hline OPT & Oil Point & 59.6527 & -153.2297 & 450 & UAGI & $88 / 10 / 01$ & \\
\hline PAX & Paxson & 62.9708 & -145.4687 & 1130 & UAGI & $88 / 10 / 01$ & \\
\hline PCA & [See Pin] & & & & & & \\
\hline $\mathrm{PCL}$ & Point Campbell & 61.1428 & -150.0155 & 90 & USGS & 73/09/04 & $74 / 09 / 30$ \\
\hline PDB & Pedro Bay & 59.7878 & -154.1925 & 305 & USGS & 78/09/09 & \\
\hline PIN & Pinnacle & 60.0967 & -140.2567 & 975 & USGS & $74 / 09 / 05$ & \\
\hline PLR & Palmer (Usgs) & 61.5922 & -149.1308 & 100 & USGS & $84 / 09 / 20$ & \\
\hline PMA & Port Moller & 55.9787 & -160.4972 & 315 & UAGI & $91 / 08 / 01$ & \\
\hline PME & Palmer East & 61.6317 & -149.0283 & 232 & NOAA & $80 / 08 / 19$ & 90/03/01 \\
\hline PMR & Palmer Observatory & 61.5922 & -149.1308 & 100 & NOAA & $67 / 09 / 01$ & \\
\hline PMS & Arctic Valley & 61.2447 & -149.5605 & 716 & NOAA & $67 / 05 / 25$ & \\
\hline${ }^{*} \mathrm{PNL}$ & Peninsula & 59.6677 & -139.3970 & 585 & USGS & $74 / 09 / 02$ & \\
\hline *PRG & Portage & 60.8645 & -149.0202 & 55 & USGS & $72 / 08 / 29$ & \\
\hline PTR & Potter & 61.0575 & -149.7292 & 695 & USGS & $73 / 08 / 12$ & $74 / 09 / 15$ \\
\hline PWA & Houston & 61.6508 & -149.8787 & 137 & NOAA & $77 / 07 / 01$ & \\
\hline PWL & Port Wells & 60.8593 & -148.3348 & 549 & USGS & $74 / 08 / 03$ & \\
\hline
\end{tabular}




\begin{tabular}{|c|c|c|c|c|c|c|c|}
\hline RAG & Ragged Mountain & 60.3870 & -144.6752 & 739 & USGS & $84 / 07 / 22$ & \\
\hline RAI & Raspberry Island & 58.0605 & -153.1592 & 520 & UAGI & $75 / 10 / 00$ & \\
\hline RDS & Richard D. Siegrist & 64.8265 & -148.1447 & 510 & UAGI & $77 / 06 / 12$ & $91 / 07 / 18$ \\
\hline${ }^{*} \mathrm{RDT}$ & Redoubt & 60.5732 & -152.4053 & 930 & USGS & $71 / 08 / 09$ & $90 / 07 / 19$ \\
\hline RED & Redoubt Volcano & 60.4198 & -152.7718 & 1064 & UAGI & $81 / 11 / 10$ & \\
\hline RGD & Ragged Mountain & 60.2192 & -144.5457 & 610 & USGS & $74 / 09 / 30$ & $77 / 08 / 16$ \\
\hline RIU & Riou & 59.8775 & -141.2300 & 15 & USGS & $76 / 08 / 03$ & $81 / 09 / 28$ \\
\hline RND & Reindeer & 63.4062 & -148.8528 & 991 & UAGI & $88 / 10 / 01$ & \\
\hline RON & Remote & 62.6912 & -150.2035 & 470 & UAGI & $71 / 09 / 22$ & $74 / 10 / 31$ \\
\hline SAW & Sawmill & 61.8082 & -148.3330 & 740 & USGS & $73 / 08 / 31$ & \\
\hline SCF & Sheep Creek Facility & 61.9947 & -150.0392 & 67 & UAGI & $71 / 09 / 21$ & $75 / 10 / 7$ \\
\hline SCM & Sheep Mountain & 61.8333 & -147.3277 & 1020 & UAGI & $91 / 08 / 01$ & \\
\hline SCT & Scotty Lake & 62.3192 & -150.2972 & 140 & UAGI & $71 / 09 / 21$ & $75 / 06 / 0$ \\
\hline SDE & Sadie Cove & 59.4433 & -151.2820 & 770 & USGS & $83 / 07 / 04$ & $84 / 06 / 28$ \\
\hline SDG & Sourdough & 62.5270 & -145.5433 & 625 & UAGI & $86 / 01 / 00$ & \\
\hline SDN & Sand Point & 55.3413 & -160.4972 & 23 & NOAA & $78 / 10 / 11$ & \\
\hline SGA & Sherman Glacier & 60.5340 & -145.2070 & 424 & USGS & $76 / 08 / 16$ & \\
\hline SHU & Shuyah Island & 58.6280 & -152.3488 & 34 & UAGI & $74 / 00 / 00$ & $90 / 08 / 27$ \\
\hline SII & Sitkinak Island & 56.5600 & -154.1820 & 500 & UAGI & $75 / 08 / 09$ & \\
\hline SIT & Sitka & 57.0570 & -135.3245 & 19 & NOAA & $40 / 00 / 00$ & \\
\hline SIY & Silver City & 61.0317 & -138.4063 & 785 & GSC & $79 / 12 / 05$ & $80 / 03 / 27$ \\
\hline SKD & Sitkalidak Island & 57.1642 & -153.0803 & 135 & UAGI & 70/01/01 & \\
\hline *SKL & Skilak & 60.5143 & -150.2160 & 640 & USGS & 71/09/09 & $84 / 07 / 28$ \\
\hline *SKN & Skwentna & 61.9803 & -151.5297 & 564 & USGS & $72 / 08 / 08$ & \\
\hline SLK & Skilak & 60.5123 & -150.2210 & 655 & USGS & $84 / 07 / 29$ & \\
\hline SLV & Seldovia & 59.4713 & -151.5805 & 91 & USGS & $72 / 09 / 30$ & $85 / 06 / 29$ \\
\hline SMY & Shemya & 52.7308 & 174.1030 & 58 & NOAA & $70 / 11 / 17$ & \\
\hline SPU & Spurr & 61.1817 & -152.0543 & 800 & USGS & $71 / 08 / 10$ & \\
\hline SSN & Susitna & 61.4638 & -150.7433 & 1297 & USGS & $72 / 08 / 15$ & \\
\hline SSP & Sunshine Point & 60.2050 & -142.8300 & 305 & USGS & $74 / 09 / 10$ & \\
\hline SST & Susitna & 61.4342 & -150.7803 & 780 & USGS & $71 / 08 / 24$ & $72 / 08 / 9$ \\
\hline STG & Stephens Glacier & 61.4207 & -146.3948 & 1326 & USGS & $74 / 07 / 11$ & $76 / 01 / 31$ \\
\hline STY & Stony River & 61.1445 & -154.2018 & 1047 & USGS & $72 / 07 / 24$ & $75 / 07 / 28$ \\
\hline SUK & Suckling Hills & 60.0737 & -143.7770 & 454 & USGS & $74 / 10 / 02$ & $85 / 08 / 10$ \\
\hline SVG & Savoonga & 63.6950 & -170.4800 & 15 & UAGI & $77 / 08 / 17$ & \\
\hline SVW & Sparrevohn & 61.1082 & -155.6217 & 762 & NOAA & $67 / 08 / 0$ & \\
\hline SWD & Seward & 60.1037 & -149.4493 & 91 & USGS & $72 / 08 / 22$ & \\
\hline TGL & Tana Glacier & 60.7558 & -142.8297 & 1234 & USGS & $88 / 07 / 01$ & \\
\hline TLK & Talkeetna Mountains & 62.4938 & -147.8780 & 1719 & USGS & $74 / 07 / 10$ & $76 / 07 / 01$ \\
\hline
\end{tabular}




\begin{tabular}{|c|c|c|c|c|c|c|c|}
\hline TMW & Tok Microwave & 63.3213 & -142.9913 & 488 & UAGI & $90 / 08 / 20$ & \\
\hline TNN & Tanana & 65.2567 & -151.9117 & 504 & UAGI & $65 / 01 / 00$ & $79 / 01 / 03$ \\
\hline TOA & Tolsona & 62.1048 & -146.1723 & 909 & NOAA & $71 / 09 / 15$ & \\
\hline TSI & Tsina & 61.2262 & -145.3373 & 1113 & USGS & $76 / 08 / 15$ & $85 / 07 / 17$ \\
\hline TTA & Tatalina & 62.9300 & -156.0220 & 914 & NOAA & $78 / 09 / 20$ & \\
\hline TTV & Terentiev Lake & 61.0548 & -147.1215 & 533 & USGS & $84 / 09 / 19$ & $85 / 07 / 14$ \\
\hline TZO & Tzero & 63.8027 & -145.7350 & 602 & UAGI & $87 / 10 / 00$ & $89 / 07 / 17$ \\
\hline *VLZ & Valdez & 61.1322 & -146.3338 & 17 & USGS & $71 / 09 / 02$ & \\
\hline VZS & Valdez South & 61.0442 & -146.3053 & 668 & USGS & $72 / 07 / 22$ & $76 / 08 / 15$ \\
\hline VZW & Valdez West & 61.0590 & -146.5540 & 796 & USGS & $72 / 07 / 17$ & \\
\hline WAX & Waxell Ridge & 60.4482 & -142.8510 & 991 & USGS & $75 / 08 / 22$ & \\
\hline WHC & Whitehorse & 60.7367 & -135.0983 & 732 & GSC & $71 / 09 / 01$ & \\
\hline WLM & Willow Mountain & 61.7737 & -145.1980 & 985 & USGS & 71/09/01 & $72 / 08 / 00$ \\
\hline WRG & White River Glacier & 60.0375 & -142.0328 & 550 & USGS & $74 / 09 / 10$ & \\
\hline WRH & Wood River Hill & 64.4713 & -148.0898 & 314 & UAGI & $83 / 09 / 16$ & \\
\hline XLV & Seldovia & 59.4547 & -151.6717 & 320 & UAGI & $91 / 06 / 20$ & \\
\hline YAH & Yahtse & 60.3585 & -141.7450 & 2135 & USGS & $74 / 09 / 05$ & \\
\hline YKA & Yellowknife Array & 62.4932 & -114.6053 & 200 & GSC & $62 / 00 / 00$ & \\
\hline YKC & Yellowknife & 62.4783 & -114.4733 & 198 & GSC & $64 / 07 / 15$ & \\
\hline YKG & Yakataga & 60.0700 & -142.4222 & 46 & USGS & $72 / 10 / 08$ & $85 / 09 / 03$ \\
\hline YKT & Yakutat & 59.4517 & -138.8770 & 372 & USGS & $72 / 10 / 06$ & $74 / 09 / 30$ \\
\hline YKU & Yakutat & 59.5538 & -139.7250 & 40 & NOAA & $78 / 09 / 20$ & \\
\hline BRLK & Bradley Lake & 59.7638 & -150.8897 & 622 & USGS & $80 / 10 / 11$ & $84 / 06 / 30$ \\
\hline BRNE & Bradley Lake NE & 59.9108 & -150.6522 & 1219 & USGS & $80 / 10 / 12$ & $84 / 06 / 28$ \\
\hline BRNW & Bradley Lake NW & 59.8375 & -151.1692 & 582 & USGS & $80 / 10 / 03$ & $84 / 06 / 28$ \\
\hline BRSE & Bradley Lake SE & 59.7055 & -150.6708 & 975 & USGS & $80 / 10 / 10$ & $87 / 07 / 02$ \\
\hline BRSW & Bradley Lake SW & 59.6410 & -151.0448 & 951 & USGS & $80 / 10 / 12$ & $84 / 06 / 28$ \\
\hline $\mathrm{CBHL}$ & Heather Lake & 61.0292 & -146.9313 & 3 & USGS & $83 / 07 / 14$ & $83 / 09 / 30$ \\
\hline CBKL & Kadin Lake & 61.1105 & -147.1935 & 275 & USGS & $83 / 07 / 15$ & $83 / 09 / 30$ \\
\hline CBLB & Long Bay & 60.9655 & -147.2217 & 5 & USGS & $83 / 07 / 15$ & $83 / 09 / 30$ \\
\hline CBUI & Unakwik Inlet & 60.9110 & -147.5453 & 8 & USGS & $83 / 09 / 11$ & $83 / 09 / 30$ \\
\hline $\mathrm{ECNI}$ & Chenega Island & 60.2823 & -148.0352 & 4 & USGS & $87 / 07 / 09$ & $87 / 08 / 07$ \\
\hline EFLB & Foul Bay & 60.5823 & -148.0608 & 4 & USGS & $87 / 07 / 09$ & $87 / 08 / 07$ \\
\hline EGRI & Green Island & 60.2922 & -147.3895 & 4 & USGS & $87 / 07 / 09$ & $87 / 08 / 07$ \\
\hline ELAI & Latouche Island & 60.0613 & -147.8183 & 4 & USGS & $87 / 07 / 09$ & $87 / 08 / 07$ \\
\hline EMTC & Montana Creek & 62.1592 & -150.0167 & 131 & USGS & $86 / 08 / 28$ & $86 / 09 / 11$ \\
\hline ENKI & Naked Island & 60.6307 & -147.4592 & 4 & USGS & $87 / 07 / 09$ & $87 / 08 / 07$ \\
\hline EPKS & Parks Highway & 62.2550 & -150.2417 & 99 & USGS & $86 / 08 / 28$ & $86 / 09 / 11$ \\
\hline ETAL & Talkeetna & 62.3042 & -150.0820 & 137 & USGS & $86 / 08 / 28$ & $86 / 09 / 11$ \\
\hline
\end{tabular}




\begin{tabular}{|l|l|r|r|r|c|l|l|}
\hline EWTF & West Fork & 62.3188 & -150.4758 & 200 & USGS & $86 / 08 / 28$ & $86 / 09 / 11$ \\
\hline GALN & Galena Bay & 60.9578 & -146.7413 & 3 & USGS & $72 / 07 / 14$ & $72 / 08 / 13$ \\
\hline JACK & Jack Bay & 61.0043 & -146.5172 & 30 & USGS & $72 / 07 / 14$ & $72 / 08 / 13$ \\
\hline LOWE & Lowe River & 61.0695 & -146.0428 & 58 & USGS & $72 / 07 / 14$ & $72 / 08 / 13$ \\
\hline MNRL & Mineral Creek & 61.2100 & -146.3193 & 236 & USGS & $72 / 07 / 14$ & $72 / 08 / 13$ \\
\hline SENW & Saint Elias NW & 60.2300 & -140.9067 & 1250 & USGS & $79 / 07 / 20$ & $79 / 08 / 17$ \\
\hline SHOU & Shoup Bay & 61.1307 & -146.5710 & 15 & USGS & $72 / 07 / 14$ & $72 / 08 / 13$ \\
\hline SWML & Sawmill Bay & 61.0657 & -146.7785 & 15 & USGS & $72 / 07 / 14$ & $72 / 08 / 13$ \\
\hline
\end{tabular}


Table 2. Alaska Velocity Models

Model 1. Gulf of Alaska

\begin{tabular}{||c|c|c||}
\hline \hline Layer & Depth $(\mathrm{km})$ & P velocity $(\mathrm{km} / \mathrm{s})$ \\
\hline 1 & $0-7$ & 5.0 \\
\hline 2 & $7-12.5$ & 6.8 \\
\hline 3 & below 12.5 & 8.1 \\
\hline
\end{tabular}

Model 2. Southern Alaska

\begin{tabular}{||c|c|c||}
\hline Layer & Depth $(\mathrm{km})$ & P velocity $(\mathrm{km} / \mathrm{s})$ \\
\hline 1 & $0-4$ & 5.3 \\
\hline 2 & $4-10$ & 5.6 \\
\hline 3 & $10-15$ & 6.2 \\
\hline 4 & $15-20$ & 6.9 \\
\hline 5 & $20-25$ & 7.4 \\
\hline 6 & $25-33$ & 7.7 \\
\hline 7 & $33-47$ & 7.9 \\
\hline 8 & $47-65$ & 8.1 \\
\hline 9 & below 65 & 8.3 \\
\hline
\end{tabular}

Model 3. Northern Alaska

\begin{tabular}{||c|c|c||}
\hline Layer & Depth $(\mathrm{km})$ & P velocity $(\mathrm{km} / \mathrm{s})$ \\
\hline 1 & $0-24.4$ & 5.90 \\
\hline 2 & $24.4-40.2$ & 7.40 \\
\hline 3 & $40.2-76$ & 7.90 \\
\hline 4 & $76-301$ & 8.29 \\
\hline 5 & $301-545$ & 10.40 \\
\hline 6 & below 545 & 12.60 \\
\hline
\end{tabular}


Table 3. Geographical regions used to assign starting depth, velocity model, and delay models.

\begin{tabular}{|c|c|c|c||}
\hline $\begin{array}{c}\text { Earthquake } \\
\text { Location }\end{array}$ & $\begin{array}{c}\text { Trial } \\
\text { Depth }(\mathrm{km})\end{array}$ & $\begin{array}{c}\text { Velocity } \\
\text { Model }\end{array}$ & $\begin{array}{c}\text { Delay } \\
\text { Model }\end{array}$ \\
\hline Gulf of Alaska* & 10. & 1 & 2 \\
\hline Southern Alaska (South of $\left.62.5^{\circ} \mathrm{N}\right)$ & $0 ., 7.5,75$. & 2 & 1 \\
\hline Northern Alaska (North of $\left.62.5^{\circ} \mathrm{N}\right)$ & $0 ., 7.5,75$. & 3 & 1 \\
\hline
\end{tabular}

$*$ (south of a line connecting $56^{\circ} \mathrm{N}, 154^{\circ} \mathrm{W} ; 59.5^{\circ} \mathrm{N}, 146^{\circ} \mathrm{W} ; 59.7^{\circ} \mathrm{N}, 143^{\circ} \mathrm{W} ; 58.2^{\circ} \mathrm{N}, 139^{\circ} \mathrm{W}$; $\left.57.9^{\circ} \mathrm{N}, 137.3^{\circ} \mathrm{W} ; 56^{\circ} \mathrm{N}, 135^{\circ} \mathrm{W}\right)$.

Table 4. P-phase and S-phase traveltime delays

\begin{tabular}{||c|c|c|c|c||}
\hline \multirow{2}{*}{ Station } & \multicolumn{2}{|c|}{ Model 1 } & \multicolumn{2}{c||}{ Model 2 } \\
\hline HTP & P delay (sec) & S delay (sec) & P delay (sec) & S delay (sec) \\
\hline ILI & 01.10 & 00.00 & 00.00 & 00.00 \\
\hline ILM & 00.44 & 00.78 & 01.11 & 01.98 \\
\hline ILN & 00.44 & 00.78 & 00.44 & 0.783 \\
\hline NIN & 01.47 & 00.78 & 00.44 & 0.783 \\
\hline NKA & 02.16 & 02.59 & 00.67 & 01.19 \\
\hline NNL & 01.47 & 03.82 & 01.45 & 02.58 \\
\hline PWA & 00.70 & 02.59 & 00.75 & 01.34 \\
\hline RDT & 00.36 & 01.25 & 00.41 & 0.730 \\
\hline SKL & 00.10 & 00.64 & -0.74 & -1.32 \\
\hline SLK & 00.10 & 00.18 & 00.10 & 0.178 \\
\hline SPU & 00.39 & 00.18 & -0.23 & -0.41 \\
\hline SSN & 00.67 & 00.69 & 00.39 & 0.694 \\
\hline SST & 00.67 & 01.19 & 00.30 & 0.534 \\
\hline RDTE & 00.36 & 00.64 & -0.74 & 01.19 \\
\hline RDTN & 00.36 & 00.64 & -0.74 & -1.32 \\
\hline RDTZ & 00.36 & 00.64 & -0.74 & -1.32 \\
\hline \hline
\end{tabular}


Table 5. Statistics of available summary/phase data

\begin{tabular}{|r|c|l|}
\hline \multicolumn{3}{|c|}{ The total number of sum records is: 53441} \\
\hline Sum \# & type & Description of event type in column 90 of summary record \\
\hline 53,178 & Blank, 1, or E & Local or regional tectonic earthquake \\
\hline 18 & A & Artillery blast or other explosive device from military base \\
\hline 32 & G & Glacial event \\
\hline 5 & N & Nuclear blast with hypocenter solution from published catalog \\
\hline 78 & Q & Quarry/mine blast \\
\hline 107 & R & Regional earthquake with hypocenter solution from published catalog \\
\hline 11 & T & Teleseism with hypocenter solution from published catalog \\
\hline 1 & X & Volcano X or spindle \\
\hline 11 & a & a-type, VT, volcano tectonic \\
\hline
\end{tabular}




\section{APPENDIX A}

\section{Summary of HYPOELLIPSE Data Formats}

Data formats are illustrated here for many of the input and output items archived in this report. Each field includes a typical entry, an abbreviated explanation, and the format for reading the field. For more details, refer to the sections indicated in the HYPOELLIPSE manual (Lahr, 1989). Note that the formats listed below for the "Station - time dependent" and "Archive arrival time" records are for the original non-Y2K version of HYPOELLIPSE where only a two-digit year is used and does not include the century.

\section{Station - primary (See section 2.2.5)}

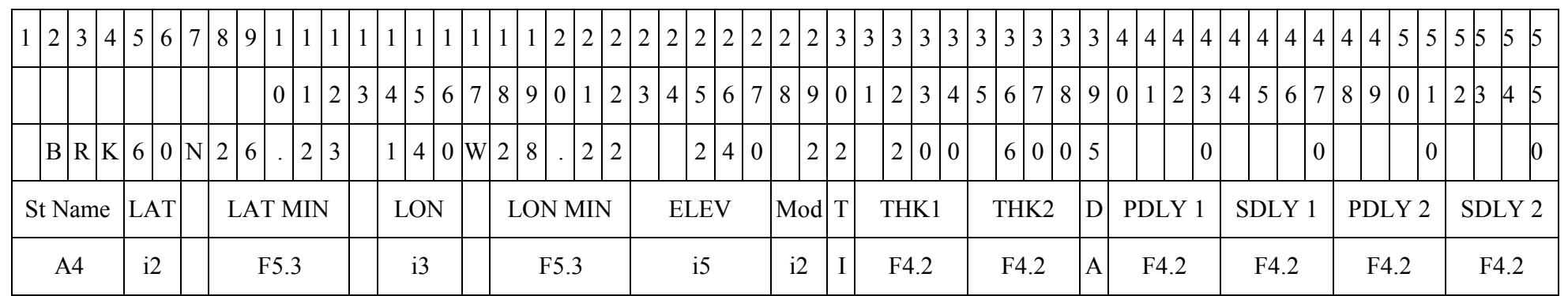

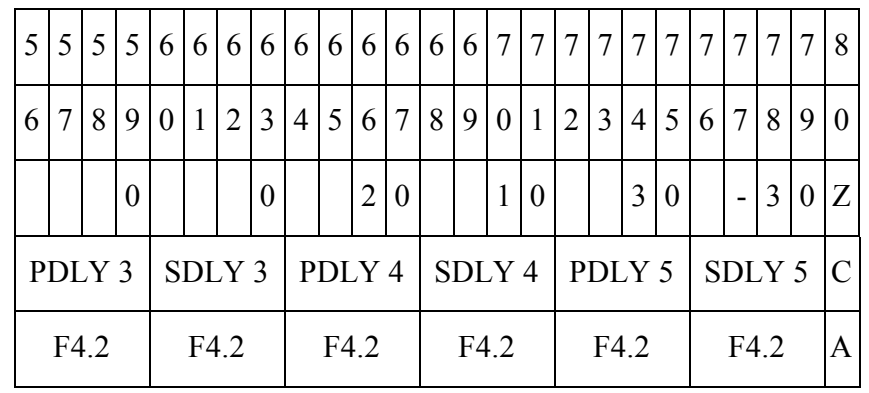


Station - time dependent (See section 2.2.5) Note: in the Y2K version (Lahr, 1999), the expiration date in columns 38-47 has a four-digit year that includes the century and is cnyrmody hr, which is read by (i8, i2).

\begin{tabular}{|c|c|c|c|c|c|c|c|c|c|c|c|c|c|c|c|c|c|c|c|c|c|c|c|c|c|c|c|c|c|c|c|c|c|c|c|c|c|c|c|c|c|c|c|}
\hline \multirow[t]{2}{*}{\begin{tabular}{l|l}
1 & 2 \\
\end{tabular}} & \multirow{2}{*}{\multicolumn{2}{|c|}{\begin{tabular}{l|l}
3 & 4
\end{tabular}}} & \multirow[t]{2}{*}{$\begin{array}{lll}4 & 5\end{array}$} & \multirow[t]{2}{*}{7} & \multirow[t]{2}{*}{$\begin{array}{lll}8 & 9\end{array}$} & \multicolumn{2}{|c|}{1} & 1 & 1 & 1 & 1 & \begin{tabular}{l|l}
1 & 1
\end{tabular} & \begin{tabular}{l|l}
1 & 2
\end{tabular} & $2 \mid 2$ & \begin{tabular}{l|l}
2 & 2
\end{tabular} & 22 & 22 & 2 & 2 & $\begin{array}{lll}2 & 2 \\
\end{array}$ & \begin{tabular}{l|l}
2 & 2 \\
\end{tabular} & 33 & 33 & 3 & 3 & 3 & 3 & 3 & 33 & \begin{tabular}{l|l}
3 & 4 \\
\end{tabular} & 4 & 44 & 4 & $4 \quad 4$ & 4 & 4 & 4 & \begin{tabular}{l|l}
4 & 5
\end{tabular} & 5 & 5 & 5 & 5 & 5 \\
\hline & & & & & & \begin{tabular}{l|l}
0 & 1
\end{tabular} & \begin{tabular}{l|l}
1 & 2
\end{tabular} & 3 & 45 & 56 & \begin{tabular}{l|l|}
6 & 7
\end{tabular} & 8 & \begin{tabular}{l|l}
9 & 0 \\
\end{tabular} & \begin{tabular}{l|l}
0 & 1
\end{tabular} & 12 & 3 & 4 & 5 & 7 & 8 & 9 & 0 & 12 & 3 & 4 & 5 & 6 & 7 & \begin{tabular}{l|l}
8 & 9
\end{tabular} & \begin{tabular}{l|l|}
9 & 0 \\
\end{tabular} & 1 & 23 & 4 & \begin{tabular}{l|l}
4 & 5
\end{tabular} & 6 & 7 & 8 & \begin{tabular}{l|l}
9 & 0
\end{tabular} & 1 & 2 & 3 & 4 & 5 \\
\hline B & $\mathrm{R}$ & K & * & 1 & & 9 & 9 & & 49 & 9 & & 8 & \begin{tabular}{l|l}
0 & 0 \\
\end{tabular} & & & & & 1 & 0 & & 1 & c & & & & & 3 & 2 & 89 & \begin{tabular}{l|l}
9 & 1
\end{tabular} & 2 & \begin{tabular}{l|l}
3 & 1
\end{tabular} & 2 & 23 & 0 & 2 & & -2 & 7 & & & & \\
\hline St & Code & & * & ST & WT & SYS & & $5 \mathrm{~Hz}$ & $\mathrm{Cal}$ & & $\mathrm{Xm}$ & ang & $\mathrm{C} 10$ & & $\mathrm{XM}$ & $\mathrm{g} \mathrm{Cc}$ & & X & $\mathrm{F}$ & & $\mathrm{Mg}$ & Cor & $\begin{array}{rl}r & P\end{array}$ & S & & $\mathrm{G}$ & $\mathrm{N}$ & $\mathrm{A}$ & & $\mathrm{R} N$ & MO & DY & & HR & $\mathrm{M}$ & & & $\mathrm{el} \mathrm{Co}$ & & $\mathrm{X}$ & $\mathrm{X}$ & & $X$ \\
\hline & A4 & & $\mathrm{A}$ & & 4.2 & i2 & & F4. & 4.0 & & & F5.2 & & & & 4.2 & & I & I & & $\mathrm{F} 4$ & & I & I & & $\mathrm{i}$ & 2 & I & & i6 & & & & & i4 & & & $\mathrm{F} 4.2$ & & A & A & $\mathrm{A}$ & A \\
\hline
\end{tabular}

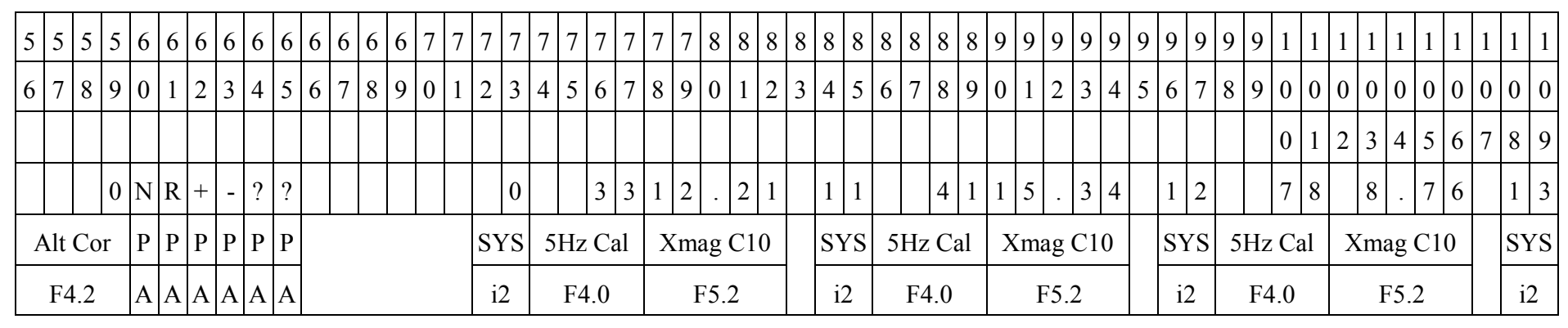

\begin{tabular}{|c|c|c|c|c|c|c|c|c|c|c|c|c|c|c|c|c|}
\hline 1 & \begin{tabular}{l|l}
1 & 1
\end{tabular} & $1 \mid 1$ & 1 & \begin{tabular}{l|l}
1 & 1
\end{tabular} & $\begin{array}{ll}1 & 1\end{array}$ & 1 & 1 & \begin{tabular}{l|l}
1 & 1
\end{tabular} & 1 & 1 & \begin{tabular}{l|l}
1 & 1
\end{tabular} & 1 & $\begin{array}{lll}1 & 1\end{array}$ & $1 \quad 1$ & 1 & \begin{tabular}{l|l}
1 & 1
\end{tabular} \\
\hline 1 & \begin{tabular}{l|l}
1 & 1
\end{tabular} & $1 \mid 1$ & 1 & \begin{tabular}{l|l}
1 & 1
\end{tabular} & 1 & 1 & 12 & 22 & 2 & 2 & 22 & 2 & 22 & 22 & 3 & 33 \\
\hline 0 & \begin{tabular}{l|l}
1 & 2 \\
\end{tabular} & 23 & 4 & $\begin{array}{lll}5 & 6 \\
\end{array}$ & 67 & 8 & 9 & \begin{tabular}{l|l}
0 & 1 \\
\end{tabular} & 2 & 3 & $4 \mid 5$ & 66 & 78 & 89 & 0 & 12 \\
\hline & \begin{tabular}{l|l}
1 & 5
\end{tabular} & $5 \mid 4$ & & 5 & 2 & 1 & 2 & 7 & 2 & 3 & 29 & & 22 & & 3 & 90 \\
\hline \multicolumn{3}{|c|}{$5 \mathrm{~Hz} \mathrm{Cal}$} & \multicolumn{4}{|c|}{ Xmag C10 } & \multicolumn{4}{|c|}{ Revised Lat } & \multicolumn{3}{|c|}{ Revised Lon } & \multicolumn{3}{|c|}{ Rev Elev } \\
\hline \multicolumn{3}{|c|}{ F4.0 } & \multicolumn{4}{|c|}{ F5.2 } & \multicolumn{4}{|c|}{ F5.3 } & \multicolumn{3}{|c|}{ F5.3 } & & \multicolumn{2}{|c|}{ i4 } \\
\hline
\end{tabular}


Arrival time (See section 2.2.6.2)

\begin{tabular}{|c|c|c|c|c|c|c|c|c|c|c|c|c|c|c|c|c|c|c|c|c|c|c|c|c|c|c|c|c|c|c|c|c|c|c|c|c|c|c|c|c|c|c|}
\hline \multirow{2}{*}{12} & \multirow[t]{2}{*}{23} & \multirow[t]{2}{*}{\begin{tabular}{l|l}
3 & 4
\end{tabular}} & \multirow[t]{2}{*}{5} & \multirow[t]{2}{*}{6} & \multirow[t]{2}{*}{78} & 8 & 1 & 1 & 1 & 1 & 1 & 1 & 1 & 1 & \begin{tabular}{l|l}
1 & 2
\end{tabular} & 22 & 2 & $22^{2}$ & 22 & $22^{2}$ & 22 & 22 & 3 & 33 & 3 & 3 & 3 & 33 & $3 \quad 3$ & 3 & $\begin{array}{lll}4 & 4\end{array}$ & 4 & 4 & 44 & 4 & 4 & $4 \quad 4$ & 5 & 55 & 5 & 5 & 5 \\
\hline & & & & & & 9 & 0 & 12 & 23 & 34 & 5 & 6 & \begin{tabular}{l|l}
7 & 8
\end{tabular} & 89 & 0 & 12 & 23 & 4 & 5 & 6 & 78 & 9 & 0 & 12 & 3 & 4 & 5 & 6 & 78 & 9 & \begin{tabular}{l|l}
0 & 1
\end{tabular} & 2 & 3 & 45 & 6 & 7 & \begin{tabular}{l|l}
8 & 9
\end{tabular} & 0 & $\begin{array}{lll}1 & 2\end{array}$ & 3 & 4 & 5 \\
\hline & B $\mathrm{F}$ & $\begin{array}{lll}\mathrm{R} & \mathrm{K}\end{array}$ & $\mathrm{I} P \mathrm{P}$ & $\mathrm{P} \mid \mathrm{U}$ & 2 & & 7 & 9 & 08 & 80 & 6 & 1 & \begin{tabular}{l|l}
0 & 4
\end{tabular} & 41 & 1 & 5 & . 3 & 1 & & & & & & 1 & 9 & & 3 & $8 \mathrm{H}$ & $E \mid S$ & . & 3 & & & & & 2 & & 0 & & & & \\
\hline & $\mathrm{Na}$ & & & $\mathrm{M}$ & W & & & YR & $\mathrm{M}$ & IO I & DY & HR & $\mathrm{MN}$ & & & $\mathrm{SE}$ & $E C$. & & & & & & & & & -SE & & & SRM & $\mathrm{IK}$ & W & & & $\mathrm{Mx}$ & $\mathrm{AM}$ & & PEF & & & & & \\
\hline & A4 & & A2 & $2 \mathrm{~A}$ & I & I & & & & & 110 & & & & & & 5.2 & & & & & & & & & F5. & & & A3 & 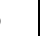 & I & & & & 4.0 & & F3. & & & & & \\
\hline
\end{tabular}

\begin{tabular}{|c|c|c|c|c|c|c|c|c|c|c|c|c|c|c|c|c|c|c|c|c|c|c|c|c|c|c|c|c|c|c|c|c|c|c|c|c|c|c|c|c|c|c|c|}
\hline 5 & 5 & 5 & 5 & 6 & 6 & 6 & $6 \quad 6$ & 6 & 66 & \begin{tabular}{l|l}
6 & 6
\end{tabular} & 6 & 7 & 77 & 77 & 7 & 7 & 7 & $7 \cdot$ & 7 & 8 & 88 & 8 & 8 & 88 & \begin{tabular}{l|l}
8 & 8
\end{tabular} & 8 & 8 & 99 & 9 & 9 & 99 & 9 & 9 & 99 & 1 & 1 & 1 & \begin{tabular}{l|l}
1 & 1
\end{tabular} & 1 & 1 & 1 & \begin{tabular}{l|l}
1 & 1
\end{tabular} & \\
\hline \multirow[t]{5}{*}{6} & 7 & 8 & 9 & 0 & 12 & 2 & \begin{tabular}{l|l}
3 & 4
\end{tabular} & 5 & \begin{tabular}{l|l}
6 & 7
\end{tabular} & 78 & 9 & 0 & 12 & 23 & 4 & 5 & 6 & 78 & 9 & 0 & 12 & 23 & 4 & 5 & $\begin{array}{lll}6 & 7\end{array}$ & 8 & 9 & $\begin{array}{lll}0 & 1\end{array}$ & 2 & 3 & 45 & 6 & 7 & 89 & 0 & 0 & 0 & \begin{tabular}{l|l}
0 & 0
\end{tabular} & 0 & 0 & 0 & \begin{tabular}{l|l}
0 & 0
\end{tabular} & \\
\hline & & & & & & & & & & & & & & & & & & & & & & & & & & & & & & & & & & & 0 & 1 & 23 & \begin{tabular}{l|l}
3 & 4
\end{tabular} & 5 & 6 & 7 & \begin{tabular}{l|l}
8 & 9
\end{tabular} & \\
\hline & & & & & 0 & 0 & $\mathrm{~T} / \mathrm{L}$ & & & & & 0 & & 2 & 0 & 0 & & & & & & & & & & & & & & & & & & & & & & & E & $\mathrm{E}$ & E & $\mathrm{E} E$ & \\
\hline & & & & & $\mathrm{S}$ & $\mathrm{V}$ & Rmk & & & $\operatorname{Tim}$ & Cor & & & $\mathrm{P}$ Ti & ime & & & & & & & & & & & & & & & & & & & & & & & & $\mathrm{P}$ & $\mathrm{P}$ & $S$ & $\mathrm{~A} C$ & \\
\hline & & & & & I & $\mathrm{I}$ & A2 & & & F5. & & & & F5. & & & & & & & & & & & & & & & & & & & & & & & & & A & $\mathrm{A}$ & A & A & \\
\hline
\end{tabular}




\section{Instruction (See section 2.2.6.3)}

\begin{tabular}{|c|c|c|c|c|c|c|c|c|c|c|c|c|c|c|c|c|c|c|c|c|c|c|c|c|c|c|c|c|c|c|c|c|c|c|c|c|c|c|c|c|}
\hline 1 & \begin{tabular}{l|l}
2 & 3
\end{tabular} & $\begin{array}{lll}3 & 4\end{array}$ & 5 & 67 & \begin{tabular}{l|l}
7 & 8
\end{tabular} & 9 & 1 & 1 & 1 & 1 & 1 & \begin{tabular}{l|l}
1 & 1
\end{tabular} & 1 & 1 & 12 & \begin{tabular}{l|l}
2 & 2
\end{tabular} & 2 & 2 & 22 & 2 & 2 & 2 & \begin{tabular}{l|l}
2 & 3
\end{tabular} & 3 & 3 & 3 & \begin{tabular}{l|l}
3 & 3
\end{tabular} & 3 & 3 & \begin{tabular}{l|l}
3 & 3
\end{tabular} & 4 & \begin{tabular}{|l|l|}
4 & 4
\end{tabular} & 4 & \begin{tabular}{l|l}
4 & 4
\end{tabular} & 4 & \begin{tabular}{l|l}
4 & 4
\end{tabular} & \begin{tabular}{l|l}
4 & 4
\end{tabular} & 5 & 55 & $\begin{array}{lll}5 & 5\end{array}$ \\
\hline & & & & & & & 0 & 1 & 2 & 3 & 4 & 56 & 57 & 8 & 9 & \begin{tabular}{l|l}
0 & 1
\end{tabular} & 2 & 3 & 45 & 6 & 7 & 8 & \begin{tabular}{l|l}
9 & 0
\end{tabular} & 1 & 2 & 3 & $4 \mid 5$ & 6 & 7 & 89 & 0 & \begin{tabular}{|l|l|}
1 & 2
\end{tabular} & 3 & \begin{tabular}{ll|}
4 & 5
\end{tabular} & 56 & \begin{tabular}{|l|l|l|l}
7 & 8
\end{tabular} & 89 & 0 & 12 & 23 \\
\hline $\mathrm{M}$ & $\mathrm{O} R$ & $\begin{array}{ll}\mathrm{R} & \mathrm{E}\end{array}$ & & & & $*$ & E & & & & & & & 1 & 0 & & & & & & & & & & & & & & & & & \begin{tabular}{|l|l|}
6 & 1 \\
\end{tabular} & $\mathrm{~N}$ & \begin{tabular}{|l|l}
3 & 1
\end{tabular} & 1 & & 2 & & & \\
\hline & PRC & & & & & $\mathrm{S}$ & $\mathrm{T}$ & & & & & & & S & $\mathrm{F}$ & & RIAI & $\mathrm{L} Z$ & & & & & & & & & & & & & & LAT & & & $\mathrm{AT} \mathrm{M}$ & MIN & & & & \\
\hline & A4 & & & & & A & A & & & & & & & $\mathrm{I}$ & I & & F5.2 & & & & & & & & & & & & & & & F2.0 & A & & F5.2 & & & & & \\
\hline
\end{tabular}

\begin{tabular}{|l|l|l|l|l|l|l|l|l|l|l|l|l|l|l|l|l|l|l|l|l|l|l|l|l|l|l|}
\hline 5 & 5 & 5 & 5 & 5 & 5 & 6 & 6 & 6 & 6 & 6 & 6 & 6 & 6 & 6 & 6 & 7 & 7 & 7 & 7 & 7 & 7 & 7 & 7 & 7 & 7 & 8 \\
\hline 4 & 5 & 6 & 7 & 8 & 9 & 0 & 1 & 2 & 3 & 4 & 5 & 6 & 7 & 8 & 9 & 0 & 1 & 2 & 3 & 4 & 5 & 6 & 7 & 8 & 9 & 0 \\
\hline 1 & 4 & 2 & W & 5 & 9 &. & 0 & 1 & & & & & & & & & 4 & 2 & 4 & 0 &. & 1 & 3 \\
\hline LON & \multicolumn{1}{|c|}{ LON MIN } & \multicolumn{1}{|c|}{ CUSP ID } & & Min & SECONDS \\
\hline F3.0 & A & \multicolumn{1}{|c|}{ F5.2 } & \multicolumn{10}{|c|}{ A10 } & & F2.0 & \multicolumn{3}{|c|}{ F5.2 } \\
\hline
\end{tabular}


Archive arrival time (See section 2.2.15) Note: the raw, uncorrected first motion data are provided in column 7 while the first motions corrected for polarity reversals are in column 65. The archived P- and S-phase arrivals times have been corrected for satellite delays. The number of satellite hops (NHOP) in the telemetry path, each producing a delay of $0.27 \mathrm{~s}$ is given in column 110. (If the P-arrival and S-arrival sources are not the same, then NHOP is set according to the P-arrival source.) A complete listing of the source codes listed in columns 105-109 which were used for Alaska processing are provided in section 4.2.2.2.

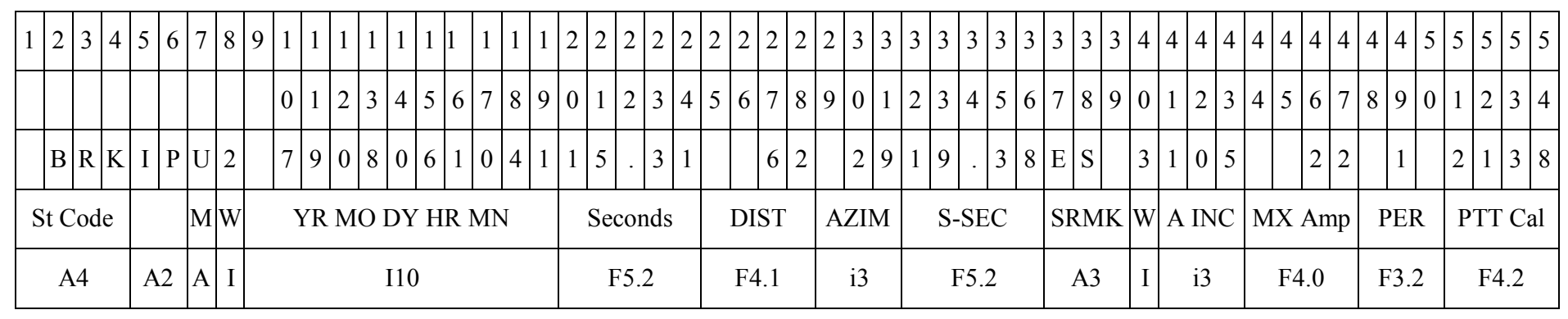

\begin{tabular}{|c|c|c|c|c|c|c|c|c|c|c|c|c|c|c|c|c|c|c|c|c|c|c|c|c|c|c|c|c|c|c|c|c|c|c|c|c|c|c|c|c|c|}
\hline 5 & 55 & 5 & 5 & 56 & 6 & 6 & \begin{tabular}{l|l}
6 & 6
\end{tabular} & 6 & 6 & 66 & \begin{tabular}{l|l|}
6 & 6
\end{tabular} & 7 & 77 & 7 & $7 \mid 7$ & 77 & \begin{tabular}{l|l}
7 & 7
\end{tabular} & 7 & 8 & \begin{tabular}{l|l}
8 & 8
\end{tabular} & 8 & 8 & \begin{tabular}{l|l}
8 & 8
\end{tabular} & 8 & \begin{tabular}{l|l}
8 & 8
\end{tabular} & 9 & 9 & 9 & 9 & 9 & \begin{tabular}{l|l|}
9 & 9
\end{tabular} & 99 & 9 & $1 \mid 1$ & \begin{tabular}{l|l}
1 & 1
\end{tabular} & 1 & 1 & 1 & 1 & & 1 \\
\hline 5 & $6 \quad 7$ & 7 & 8 & 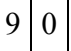 & 1 & 2 & \begin{tabular}{l|l}
3 & 4
\end{tabular} & 45 & 6 & 78 & $8 \quad 9$ & 0 & 112 & 3 & \begin{tabular}{l|l}
4 & 5
\end{tabular} & 6 & \begin{tabular}{l|l}
7 & 8
\end{tabular} & 9 & 0 & 12 & 3 & 4 & \begin{tabular}{l|l}
5 & 6
\end{tabular} & 7 & \begin{tabular}{l|l}
8 & 9
\end{tabular} & 0 & 1 & 2 & 3 & 5 & \begin{tabular}{l|l}
6 & 7
\end{tabular} & 89 & 90 & \begin{tabular}{l|l|l|l|}
0 & 0
\end{tabular} & 0.0 & 0 & 0 & 0 & 0 & & 1 \\
\hline & & & & & & & & & & & & & & & & & & & & & & & & & & & & & & & & & 0 & $1 \mid 2$ & \begin{tabular}{|l|l|l}
3 & 4
\end{tabular} & 5 & 6 & 7 & 8 & & 0 \\
\hline & 90 & 0 & $\mathrm{M}$ & $\begin{array}{ll}\mathrm{S} & \mathrm{H}\end{array}$ & 0 & 0 & $\mathrm{~T} / \mathrm{L}$ & $\mathrm{D}$ & & & & 0 & & 2 & \begin{tabular}{l|l}
0 & 0
\end{tabular} & & 6 & 2 & 1 & 13 & 1 & & & & $8 \mid 2$ & & & 0 & & 0 & 2 & 9 & 1 & $1 \mid 6$ & 23 & E & $\mathrm{E}$ & $\mathrm{E}$ & $\mathrm{E}$ & & 1 \\
\hline & $\mathrm{SE}$ & & $\mathrm{R}$ & INS & $\mathrm{S}$ & $\mathrm{V}$ & Rmk & $\mathrm{k} \mid \mathrm{M}$ & & ГIM & $\mathrm{COR}$ & & F-P & TIN & & & RES & IDU & & S S & & $\mathrm{R}$ & S R & ESI & DU & & DLY & & SDL & & EDLY & & SYS & $\mathrm{xmg}$ & fmg & $\mathrm{P}$ & $\mathrm{P}$ & $\mathrm{S}$ & A & & $\mathrm{H}$ \\
\hline & 3.2 & & A & A2 & I & $\mathrm{I}$ & A2 & A & & & 5.2 & & & F5.0 & & & F5. & & & F3. & & A & & $\mathrm{F} 5.2$ & & & F 3.1 & & F3. & & F3.1 & & i2 & F2.1 & F2.1 & A & A & A & $\mathrm{A}$ & & I \\
\hline
\end{tabular}

\section{Comment Record Codes}

\begin{tabular}{|l|l|}
\hline $\mathrm{C}^{*}$ & Routine comment record in archive arrival times pickfiles \\
\hline $\mathrm{C}^{*}(\mathrm{~F})$ & Pickfile id number \\
\hline $\mathrm{C}^{*}<\mathrm{C}>$ & Data from Geological Survey of Canada (GSC) Pacific Geoscience Centre (PGC) catalog \\
\hline $\mathrm{C}^{*}<\mathrm{I}>$ & Data from International Seismological Centre (ISC) catalog \\
\hline $\mathrm{C}^{*}<\mathrm{N}>$ & Data from USGS National Earthquake Information Center (NEIC) catalog \\
\hline
\end{tabular}


Summary (See section 2.4.1) Note: in the Y2K version, everything is pushed to the right by 2 columns to allow for the century in columns 1-2.

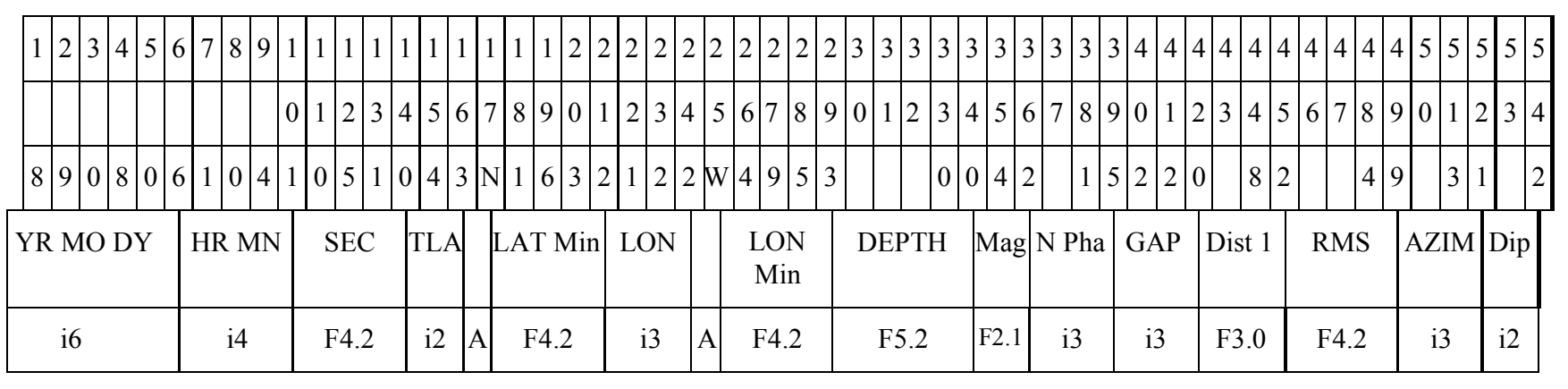

\begin{tabular}{|c|c|c|c|c|c|c|c|c|c|c|c|c|c|c|c|c|c|c|c|c|c|c|c|c|c|c|c|c|c|c|c|c|c|c|c|c|c|c|}
\hline \begin{tabular}{|l|l}
5 & 5
\end{tabular} & \begin{tabular}{ll|}
5 & 5 \\
\end{tabular} & 5 & \begin{tabular}{|l|l|}
5 & 6 \\
\end{tabular} & 6 & \begin{tabular}{l|l}
6 & 6
\end{tabular} & 66 & 66 & $\begin{array}{llll}6 & 6 & 6\end{array}$ & \begin{tabular}{l|l|l}
6 & 7 & 7
\end{tabular} & 77 & \begin{tabular}{l|l}
7 & 7
\end{tabular} & 77 & 77 & 7 & \begin{tabular}{|l|l}
7 & 8
\end{tabular} & 88 & $8 \mid \begin{array}{lll}8 & 8\end{array}$ & $\begin{array}{ll}8 & 8\end{array}$ & 8 & 88 & 8 & 9 & 9 & 99 & 9 & 9 & 9 & \begin{tabular}{l|l|}
9 & 1
\end{tabular} & 11 & 11 & & $1 \quad 1$ & 1 & \begin{tabular}{l|l}
1 & 1
\end{tabular} & & $\begin{array}{lll}1 & 1\end{array}$ & 1 & \\
\hline $5 \mid 6$ & \begin{tabular}{ll|}
6 & 7
\end{tabular} & 8 & $\begin{array}{lll}9 & 0\end{array}$ & 1 & 23 & 45 & 56 & \begin{tabular}{l|l|l}
7 & 8 & 9
\end{tabular} & \begin{tabular}{l|l|l}
9 & 0 & 1
\end{tabular} & 12 & \begin{tabular}{l|l}
3 & 4
\end{tabular} & 56 & $\begin{array}{ll}6 & 7\end{array}$ & 8 & \begin{tabular}{|l|l|l|l|l}
9 & 0
\end{tabular} & 12 & 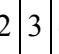 & 4 \begin{tabular}{l|l}
4 & 5
\end{tabular} & 6 & \begin{tabular}{l|l|l}
7 & 8
\end{tabular} & 9 & \begin{tabular}{l|l}
0 & 1
\end{tabular} & 2 & \begin{tabular}{l|l}
3 & 4
\end{tabular} & 56 & 57 & 85 & \begin{tabular}{l|l|l|}
9 & 0
\end{tabular} & \begin{tabular}{l|l}
0 & 0
\end{tabular} & 00 & 0 & \begin{tabular}{l|l}
0 & 0
\end{tabular} & 0 & \begin{tabular}{l|l}
0 & 1
\end{tabular} & 1 & \begin{tabular}{l|l}
1 & 1
\end{tabular} & 1 & \\
\hline & & & & & & & & & & & & & & & & & & & & & & & & & & & & 0 & 12 & $\begin{array}{lll}3 & 4\end{array}$ & & \begin{tabular}{l|l}
6 & 7
\end{tabular} & 8 & \begin{tabular}{l|l}
9 & 0
\end{tabular} & 1 & \begin{tabular}{l|l}
2 & 3
\end{tabular} & 4 & \\
\hline 8 & \begin{tabular}{ll|l}
8 & 2
\end{tabular} & 2 & \begin{tabular}{l|l|}
1 & 2 \\
\end{tabular} & 1 & 4 & & \begin{tabular}{l|l}
6 & 3
\end{tabular} & \begin{tabular}{l|l|l}
8 & 2 & 0
\end{tabular} & \begin{tabular}{l|l|l}
0 & 2 & 2
\end{tabular} & $2 \mathrm{~F}$ & 12 & 57 & $7 \mathrm{C}$ & $\mathrm{F}$ & 3 & $/ \mathrm{N}$ & $\mathrm{M} \mid \mathrm{O}$ & \begin{tabular}{l|l}
$\mathrm{R}$ & $\mathrm{E}$
\end{tabular} & 1 & \begin{tabular}{l|l|l}
0 & 7
\end{tabular} & 9 & $\mathrm{E} C$ & $\mathrm{E}$ & \begin{tabular}{l|l}
0 & 1
\end{tabular} & 93 & & $7 \mid$ & \begin{tabular}{l|l|}
8 & 1
\end{tabular} & 5 & 4 & & \begin{tabular}{l|l}
1 & 7
\end{tabular} & 7 & 3 & & - 1 & 32 & \\
\hline & D E & & AZI & & Dip & STI & TD Er & $\operatorname{rr} \mid x m g$ & $\mathrm{~g} \mid \mathrm{fmg}$ & $\mathrm{P}$ & STL & $\mathrm{D} \mathrm{Er}$ & $\mathrm{r} Q$ & $\mathrm{M}$ & NS & I & INS & $\mathrm{ST}$ & & {$[\mathrm{O} Y]$} & & $\mathrm{T} \mid \mathrm{F}$ & & Q I & NUM & & -P T & ГIM & Zup & $Z d n$ & & $\mathrm{p} / \mathrm{V}$ & & $\mathrm{WtO}$ & & DEP & & \\
\hline & 4.2 & & i3 & & i2 & & $\mathrm{F} 4.2$ & F2.1 & \begin{tabular}{l|l|l}
1 & $\mathrm{~F} 2.1$
\end{tabular} & $1 \mathrm{~A}$ & & 4.2 & A & $\mathrm{A}$ & i2 & A & A & 4 & & i4 & & A $\mid \mathrm{I}$ & & A & & & $\mathrm{F} 4$ & & $\mathrm{~F} 2.0$ & $\mathrm{~F} 2.0$ & & $\mathrm{~F} 4.2$ & & i2 & & F5. & & \\
\hline
\end{tabular}




\section{Event Type Codes}

\begin{tabular}{|l|l|}
\hline Event type code in column 90 (A1 format) of non-Y2K HYPOELLIPSE summary record \\
\hline A & Artillery blast or other explosive device from military base \\
\hline a & Volcano tectonic, a-type \\
\hline E, 1, or blank & Local or regional earthquake \\
\hline G & Glacial \\
\hline N & Nuclear blast \\
\hline Q & Quarry/mine blast \\
\hline R & Regional earthquake with location from published bulletin \\
\hline T & Teleseism \\
\hline $\mathrm{X}$ & Emergent, low frequency near volcano \\
\hline
\end{tabular}




\section{APPENDIX B}

\section{List of Previously Published Catalogs}

Lahr, J.C., Page, R.A., and Thomas, J.A., 1974, Catalog of earthquakes in south central Alaska, April-June 1972, U.S. Geological Survey Open-File Report, 35 p.

Fogleman, K.A., Stephens, Christopher, Lahr, J.C., Helton, S.M., and Allan, M.A., 1978, Catalog of earthquakes in southern Alaska, October-December 1977, U..S. Geological Survey Open-File Report 78-1097, 28 p.

Stephens, C.D., Lahr, J.C., Fogleman, K.A., Allan, M.A., and Helton, S.M., 1979, Catalog of earthquakes in southern Alaska, January-March 1978, U.S. Geological Survey Open-File Report 79-718, $31 \mathrm{p}$.

Stephens, C.D., Astrue, M.A., Pelton, J.R., Fogleman, K.A., Page, R.A., Lahr, J.C., Allan, M.A., and Helton, S.M., 1982, Catalog of earthquakes in southern Alaska, April-June 1978, U.S. Geological Survey Open-File Report 82-488, 36 p.

Stephens, C.D., Lahr, J.C., Fogleman, K.A., Helton, S.M., Cancilla, R.S., Tam, Roy and Baldonado, K.A., 1980, Catalog of earthquakes in southern Alaska, October-December 1979, U.S. Geological Survey Open-File Report 80-2002, 53 p.

Stephens, C.D., Fogleman, K.A., Lahr, J.C., Helton, S.M., Cancilla, R.S., Tam, Roy and Freiberg, J.A., 1980, Catalog of earthquakes in southern Alaska, January-March 1980, U.S. Geological Survey Open-File Report 80-1253, 55 p.

Fogleman, K.A., Stephens, C.D., Lahr, J.C., Rogers, J.A., Helton, S.M., Cancilla, R.S., Tam, Roy, Freiberg, J.A., and Melnick, J.P., 1983, Catalog of earthquakes in southern Alaska, July-September 1980, U.S. Geological Survey Open-File Report 83-15, 54 p.

Fogleman, K.A., Stephens, C.D., Lahr, J.C., and Rogers, J.A., 1986, Catalog of earthquakes in southern Alaska for 1984, U.S. Geological Survey Open-File Report 86-99, 106 p.

Fogleman, K.A., Stephens, C.D., and Lahr, J.C., 1988, Catalog of earthquakes in southern Alaska for 1985, U.S. Geological Survey Open-File Report 88-31, 113 p. 


\section{APPENDIX C}

\section{Summary of Timing Criteria}

Routine network processing.

October 1, 1971 - September 31, 1973

Time all shocks with:

A. Cook Inlet (stations west of longitude $150^{\circ} \mathrm{W}$ ):

Minimum S-P time $\leq 25 \mathrm{~s}$ and recorded at 6 or more stations (clearly recorded at 4 or more of these).

B. Valdez (stations east of $150^{\circ} \mathrm{W}$ ):

1. Minimum S-P time $\leq 20 \mathrm{~s}$ and clearly recorded at 4 or more stations including 2 of WLM, ERN, VLZ and CVA.

or

2. Minimum S-P time $\leq 10 \mathrm{~s}$ and clearly recorded at 3 stations including 2 of WLM, ERN, VLZ and CVA.

C. Well recorded regional events that have clipped traces and do not come from the Aleutians.

October 1, 1973 - September 31, 1974

Time all earthquakes with:

A. Average F-P time $\geq 30 \mathrm{~s}$. F-P is signal duration (see section on magnitude).

or

B. Average F-P time $\geq 15 \mathrm{~s}$ and minimum $\mathrm{S}-\mathrm{P}$ time $\leq 5 \mathrm{~s}$.

October 1, 1974 - January 31, 1975

Time all local events in network with average F-P time $\geq 20 \mathrm{~s}$.

February 1, 1975 - September 31, 1977

Time all shocks with:

A. WEST (stations west of $150^{\circ} \mathrm{W}$ ): Average F-P time $\geq 80 \mathrm{~s}$.

B. CENT (stations between $150^{\circ} \mathrm{W}$ and $145^{\circ} \mathrm{W}$ ): Average F-P time $\geq 20 \mathrm{~s}$.

C. EAST (stations east of $145^{\circ} \mathrm{W}$ ): All events with 3 clearly recorded P-arrivals and 1 S-arrival or $4 \mathrm{P}$-arrivals.

October 1, 1977 - September 31, 1980 
Time all shocks within the area $58-64^{\circ} \mathrm{N}$ and $134-156^{\circ} \mathrm{W}$ (eastern border moved to $134^{\circ} \mathrm{W}$ from $136^{\circ} \mathrm{W}$ ) with:
A. WEST: Average F-P time $\geq 80 \mathrm{~s}$.
B. CENT: Average F-P time $\geq 20 \mathrm{~s}$.
C. EAST: All events with 3 clearly recorded P-arrivals and $1 \mathrm{~S}$-arrival or $4 \mathrm{P}$-arrivals on SCAN and/or EAST films.

October 1, 1980 - June 30, 1981

Time all shocks within the area $58-64^{\circ} \mathrm{N}$ and $134-156^{\circ} \mathrm{W}$ with:
A. WEST (West of $145^{\circ} \mathrm{W}$ ): Average F-P time $\geq 30 \mathrm{~s}$ (WEST and CENT regions combined)
B. EAST: All events with 3 clearly recorded P-arrivals and $1 \mathrm{~S}$-arrival or $4 \mathrm{P}$-arrivals on SCAN and/or EAST films.

July 1, 1981 - September 30, 1981

Time all shocks within the area $58-64^{\circ} \mathrm{N}$ and $134-156^{\circ} \mathrm{W}$ with:

A. WEST: Average F-P time $\geq 30 \mathrm{~s}$.

B. EAST:

1. All events with 3 clearly recorded $\mathrm{P}$-arrivals and $1 \mathrm{~S}$-arrival or $4 \mathrm{P}$-arrivals on SCAN film only.

or

2. If an event has a coda on the SCAN film F-P time $\geq 10 \mathrm{~s}$ but does not have 4 P's or 3 P's and $1 \mathrm{~S}$, check the EAST film for additional arrivals and time if have 4 P's or 3 P's and $1 \mathrm{~S}$ on SCAN plus EAST.

or

3. If at any time less than five stations are operating east of $145^{\circ} \mathrm{W}$ use both SCAN plus EAST films to see if have $4 \mathrm{P}$-arrivals or $3 \mathrm{P}$-arrivals and $1 \mathrm{~S}$-arrival.

December 1, 1980 - May 31, 1989

No rereads on magnitude $\mathrm{M}<1.0$ events unless solution is unacceptable.

October 1, 1981 - March 31, 1984

Network borders for timing reduced to decrease the number of earthquakes processed per month. Northern border moved from $64^{\circ} \mathrm{N}$ to $63^{\circ} \mathrm{N}$. Less emphasize placed on rereading events between latitude $58-59^{\circ} \mathrm{N}$ and longitude $134-138^{\circ} \mathrm{W}$.

Time all shocks within the area $58-63^{\circ} \mathrm{N}$ and $134-156^{\circ} \mathrm{W}$ with:

A. WEST: Average F-P time $\geq 30 \mathrm{~s}$.

B. EAST (same as B for July 1 - September 30, 1981) 
April 1, 1984 - August 31, 1985

Time all shocks within the area $58-62.5^{\circ} \mathrm{N}$ (northern border moved from $63.0^{\circ} \mathrm{N}$ to $62.5^{\circ} \mathrm{N}$ ) and $134-156^{\circ} \mathrm{W}$ with:
A. WEST: Average F-P time $\geq 30 \mathrm{~s}$.
B. EAST (same as B for July 1 - September 30, 1981)
C. Time any earthquake with S-P time $\leq 2$ s on SCAN film station except for AGA whose S-P time must be $\leq 1.75 \mathrm{~s}$.

September 1, 1985 - May 31, 1989

Time all shocks within the area $58-62.5^{\circ} \mathrm{N}$ and $138-156^{\circ} \mathrm{W}$ (eastern borders moved from $134^{\circ} \mathrm{W}$ to $138^{\circ} \mathrm{W}$ due to major reduction of recordable stations in east) with:
A. WEST: Average F-P time $\geq 30 \mathrm{~s}$.
B. EAST (same as B for July 1 - September 30, 1981) 
C. Time any earthquake with S-P time $\leq 2 \mathrm{~s}$ on SCAN film station except for AGA whose S-P time must be $\leq 1.75 \mathrm{~s}$.

\section{$\underline{\text { Special Studies }}$}

1. Special study of microearthquakes around Anchorage.

Time all shocks with:

January 1, 1979 - December 31, 1979

A. S-P time $\leq 13.5 \mathrm{~s}$ at $\mathrm{KNK}$

and

B. P-arrival at SPU or MSP or SKL before TOA and VZW.

January 1, 1980 - March 31, 1984

A. S-P time $\leq 10 \mathrm{~s}$ at PMS

and

B. at least one station other than PMS with a F-P coda above $1 \mathrm{~cm}$ pk-to-pk for at least $5 \mathrm{~s}$.

April 1, 1984 - May 31, 1989

A. S-P time $\leq 5 \mathrm{~s}$ at PMS or SSN

and

B. At least one station other than PMS with a F-P coda above $1 \mathrm{~cm}$ pk-to-pk for at least $5 \mathrm{~s}$.

2. Special criterion for reduction in timing of aftershocks of February 28, 1979 St. Elias earthquake.

April 1 - September 30, 1979

A. If CHX is operational and YAH or PIN is working, do not time shocks where:

1. CHX S-P time $<6 \mathrm{~s}$.

and

2. YAH or PIN F-P time $<40 \mathrm{~s}$ (changed to $25 \mathrm{~s}$ for May - September). and

3. GYO P-arrival $\leq 4 \mathrm{~s}$ before CHX P-arrival.

B. If $\mathrm{CHX}$ is not working but $\mathrm{GYO}$ is, do not time events where:

1. GYO S-P $<7$ s.

and

2. YAH or PIN F-P time $<25 \mathrm{~s}$.

and

3. GYO P-arrival is before SSP P-arrival. 
C. If CHX and GYO are out, do not time events where:

1. SSP and PIN P-arrivals are approximately the same time and

2. SSP and PIN S-P time $<10 \mathrm{~s}$.

May 2-19, 1982

Special criterion for large aftershock sequence in St. Elias aftershock zone. Time only aftershocks with a measurable coda seen on SCAN film station or if YAH amplitude $\geq$ $20 \mathrm{~mm}$ pk-to-pk. This coda criteria only applied to shocks where YAH, WRG, and PIN were first three stations seen on SCAN and their S-P intervals were about 7 to $9 \mathrm{~s}$.

April 1, 1984 - September 4, 1985

Do not locate events near Icy Bay with:

A. S-P time $\leq 4 \mathrm{~s}$ at AGA (or S-P time $\leq 5 \mathrm{~s}$ at $\mathrm{CHX}$ if AGA out) and

B. F-P time at YAH and PIN $<10$ s. (or F-P time $<8$ s at AGA if YAH and PIN are dead)

3. Bradley Lake array on southern Kenai Peninsula

November 27, 1980 - January 31, 1981

Time any event with S-P time $\leq 10 \mathrm{~s}$ at any Bradley Lake station (BRLK, BRNE, BRNW, BRSE, and BRSW).

February 1, 1981 - September 31, 1981

Time any shock with S-P time $\leq 12 \mathrm{~s}$ at any Bradley Lake station.

October 1, 1981 - February 28, 1983

Time any shock with S-P time $\leq 12 \mathrm{~s}$ at any Bradley Lake station excluding events that arrive at ILM or RDT before SLV, or BRNE, or BRSW, or BRSE.

March 1, 1983 - February 28, 1985

Time any earthquake with S-P time $\leq 6 \mathrm{~s}$ at one of the Bradley Lake stations or SLV or SWD.

March 1, 1985 - September 19, 1986

Time all events with S-P time $\leq 3.5 \mathrm{~s}$ at BRLK.

4. $\quad$ Cook Inlet volcanoes

July 1, 1981 - May 31, 1989

Time any earthquake with S-P time $\leq 5 \mathrm{~s}$ at SPU, RDT, or ILM on SCAN film.

5. Aftershocks of August 14,1984 , Sutton $\mathrm{m}_{\mathrm{b}}$ 5.7 event

September 11, 1984 - April 30, 1986

Time all earthquakes with GHO S-P time $\leq 4 \mathrm{~s}$ and KNK F-P time $\geq 8$ s on SCAN film. 


\section{6. $\quad$ Knight Island in Prince William Sound}

July 7, 1985 - August 31, 1985

Timed all earthquakes which:

A. Have $\mathrm{O}$ wt. P arrivals on KNI, LOU, GBY

and

B. KNI P-arrival is before GLI and MTU P-arrivals

and

C. GBY S-P $\leq 8 \mathrm{~s}$.

and

D. A measurable coda on KNI or LOU or GBY or pk-to-pk amplitude $\geq 10 \mathrm{~mm}$ on all three stations (KNI, LOU, GBY).

September 1, 1985 - December 31, 1987

Time all shocks with KNI $\mathrm{S}-\mathrm{P} \leq 7 \mathrm{~s}$ and $\mathrm{F}-\mathrm{P} \geq 8 \mathrm{~s}$.

7. Montague Island in southern Prince William Sound

September 1, 1985 - April 30, 1986

Time all events with MTU S-P $\leq 5 \mathrm{~s}$.

\section{Joint USGS/GIUA data set}

July 1, 1988 - May 31, 1989

Starting in July 1988, the Geophysical Institute of the University of Alaska (GIUA), Fairbanks began recording 13 USGS stations along with their own network. The GIUA locates all events triggered on by their automatic detection and recording system regardless of magnitude or location. Consequently, the GIUA locates shocks within the USGS routine processing borders that would normally not be processed by the USGS. Duplicate readings from USGS stations taken by GIUA staff for earthquakes also processed by the USGS were often weighted out.

9. Merging of data from published bulletins

Data from the National Earthquake Information Center (NEIC), the International Seismological Centre (ISC), and/or the Pacific Geoscience Center (PGC) were added to this catalog during select time periods to improve hypocenter solutions, to facilitate reviews of the seismicity and to improve the magnitude threshold for completeness. 